هجلة كلية التربية الرياضية .... جاهعة بغداد ..... المجلد r....... العدد 1.

\title{
تأثير تمرينات هتندوعة في تطوير السرعة القصوى \\ والقوة المميزة بالسرعة وانجاز (مroم) سباحة حرة \\ لذوي التخلف العقلي البسيط
}

زاهيسة صبـاه عبـد السـلام

كلية التربية الرياضية / جامعة بغداد

pr..A

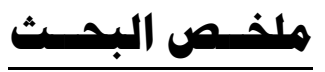

تعد رياضة السباحة واحدة من الرياضـات التي مارسـها المعاقون بصورة عامـة وإلمعاقون عقلياً

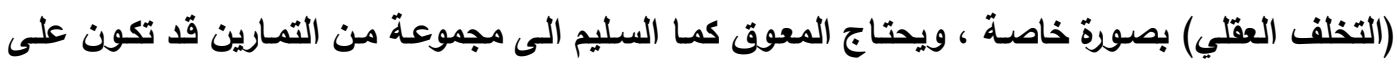
اليابسة او في الماء الغرض منها زيادة السرعة القصوى والقوة المميزة بالسرعة وفي الوقت نفسـه تحسين انجازه وتعتقد الباحثة ان تدريب هذه الثريحة يفتقد الى استخدام تمرينات متنوعة لتسـاعده على تطوير قدراته البذنية والمهارية. تكمن مشكلة البحث من خـلال الضعف الواضـح في سرعة وقوة سباحي المسـافات القصبرة من ذوي التخلف العقلي البسيط وتعتقد الباحثة أن السبب يعود الى ممارستهم لتمارين متثـابهة دائمـاً وإغلبها داخل حوض السباحة دون استخدام تمارين متنوعة كتمرينات اليابسة وكذلك عدم استخدام بعض الوسيائل

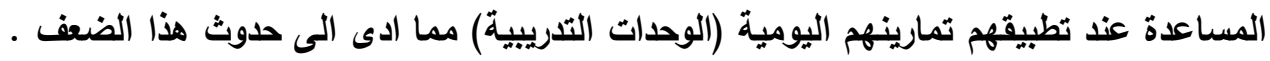

$$
\text { أما أهداف البحث فكاتت : }
$$

1. وضع تمرينات متنوعة على اليابسة والمـاء في تطوير السرعة القصوى والقوة المميزة بالسرعة

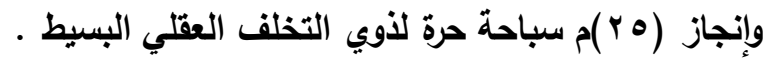

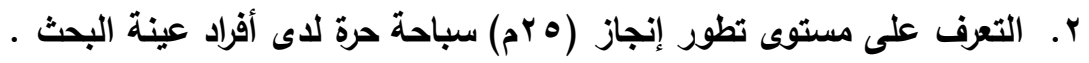

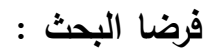




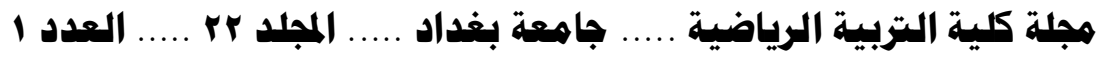

ا. أن للتمرينـات المتنوعـة تأثيراً ذا دلالـة إحصـائية على السرعة القصوى والقوة المميزة بالسرعة

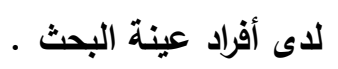

r. وجـود فروق دالـة إحصـائياً بين الاختبارين القبلي والبعدي في تطوير السرعة القصوى والقوة

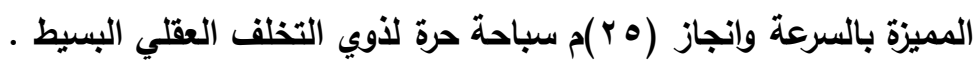

وقد استخدمت الباحثة المنهج التجريبي ذات المجموعة التجريبية الواحدة لملائمتها مشكلة البحث ،

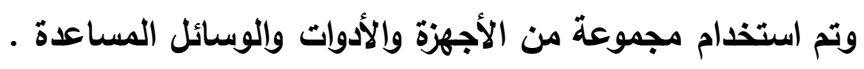$$
\text { وقد توصلت الباحثة إلى الاستتتاجات التالية : }
$$

ا. إن التمارين المتنوعة في الماء واليابسة أدت إلى تطوير السرعة القصوى التهات والقوة المميزة بالسرعة

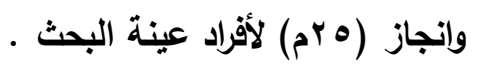

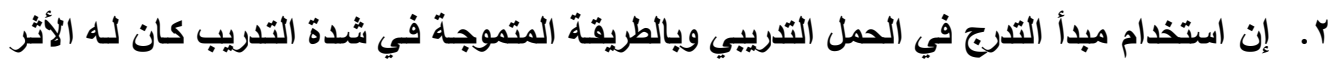

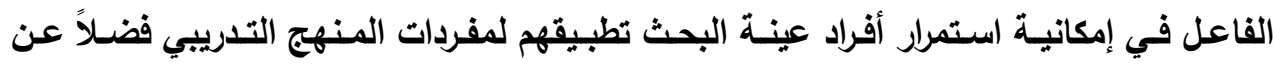

استخدام بعض الحوافز من الجوائز والهدايا .

\section{$\underline{\text { Abstract }}$}

Swimming is considered one of the first sports that disabled people practice in general and mentally disabled in particular. This sport has a special place in Olympics and for both genders. Mentally disabled swimmers are in a desperate need for increasing the level of their High speed, power speed and achievement

The problem of the study lies in the weakness of High speed and power speed in swimmers with simple mental disability. The researcher believes that this weakness is due to their fixation on one set of exercise as well as not using assisting styles.

Aims of the study:

1. Designing varied exercises on land and in water to develop the High speed, power speed and achieving $25 \mathrm{~m}$ freestyle for the mentally disabled.

2. Identifying the level of achieving $25 \mathrm{~m}$ freestyle in the subjects. Hypotheses of The Study:

1. Varied exercises have significant statistical effect on the High speed, power speed of the subjects. 
2. There are statistical differences between pre and posttests in the development of High speed, power speed and achieving $25 \mathrm{~m}$ swimming for the mentally disabled.

The researcher used the experimental method

\section{Conclusions:}

1. Varied land and water exercises led to the development of High speed, power speed and achieving $25 \mathrm{~m}$ freestyle swimming.

2. Using the principle of progressivity in training loads had a great effect on the application of the training program as well as using rewards like prizes and gifts.

\section{البـاب الأول}

ا - التعريف بالبشث

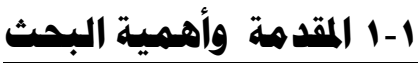

ويعد التخلف العقلي (المعاق عقلياً) واحدة من أنواع الإعاقة التي تصنف إلى ثلاثة أقسام هي

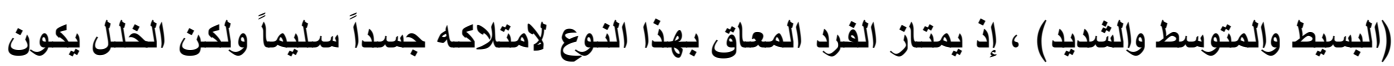

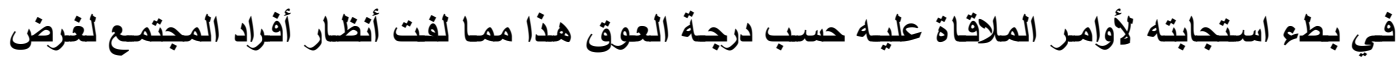
الاهتمـام بهم وتـوفير كل الفرص المناسبة لغرض الاستفادة مـن قدراتهم البدنيـة في مختلف المجـالات

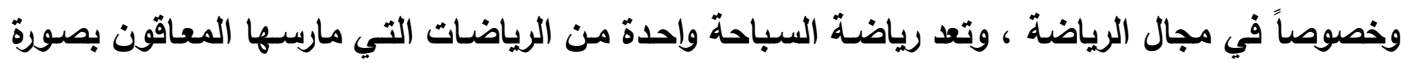

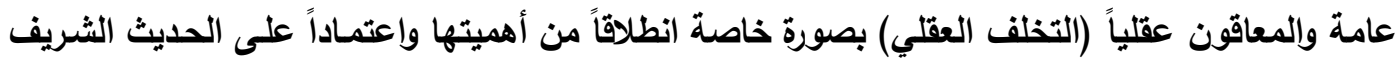
لرسولنا الأعظم محمد (ص) "علموا أولادكم السباحة والرماية وركوب الخيل " ، ويحتاج المعوق كما السليم الى مجموعة من التمـارين قد تكون على اليابسـة او في المـاء الغرض منها زيـادة قابلية القدرات البدنية وفي الوقت نفسـه تحسين انجـازه وتعتقد الباحثة ان تلدريب هذه الثـريحة يفتقد السى استخدام تمرينـات متنوعة لتساعده على تطوير قدراته البذنية وإلمهارية .

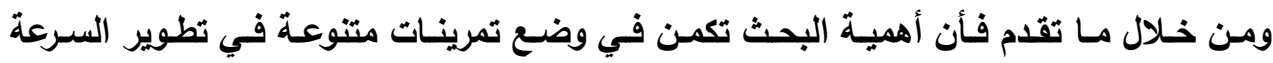

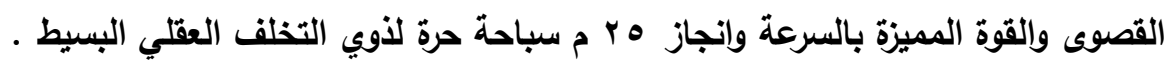


أن تنـوع التمـارين التدريبية يعد ضرورة مهمـة لارتقاء بالمستوى البدني في التدريب لمختلف

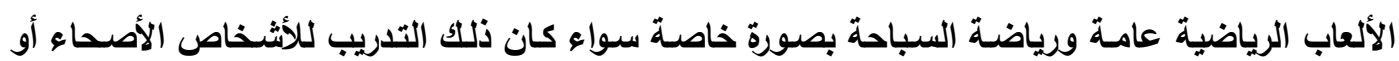

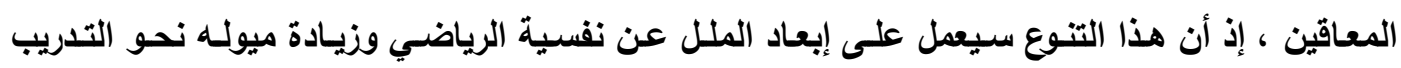

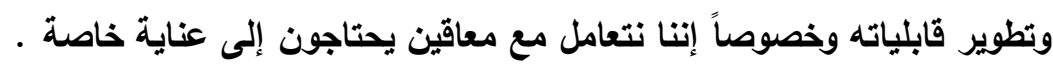

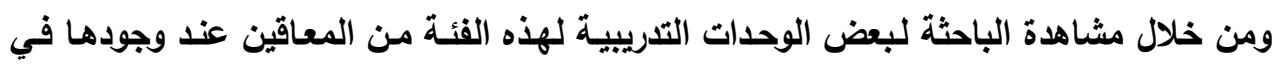

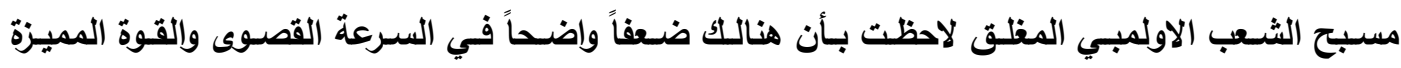
بالسـرعة لـدى سـباحي المسـافات القصيرة مـن ذوي التخلف العقلـي البسـيط بسـبب ممارستهم لتمـارين

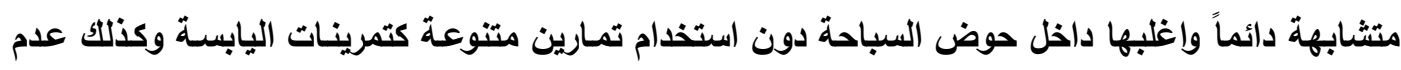

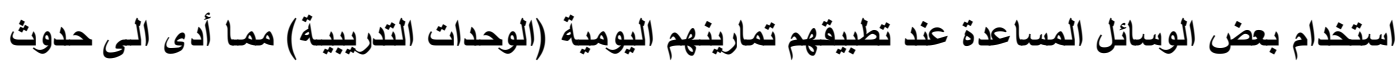
هذا الضعف. ممـا دفعت الباحثة الـى التفكير بوضـع تمـارين متنوعـة (على اليابسـة وإلمـاء) لغرض تطوير السرعة القصوى والقوة المميزة بالسرعة واتجاز (ه بم) سباحة حرة لذوي التخلف العقلي البسيط مسـاهمة منها لعلاج هذه المشكلة.

يرهاف البحث إلى :- أهداف البحث
ا ـ وضع تمرينات متنوعة على اليابسة والمـاء في تطوير السرعة القصوى والقوة المميزة بالسرعة

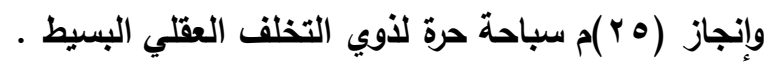

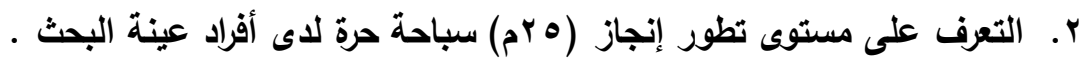

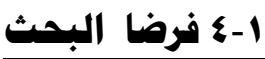

1. أن للتمرينـات المتنوعـة تأثيراً ذا دلالـة إحصـائية على السـرعة القصوى والقوة المميزة بالسـرعة

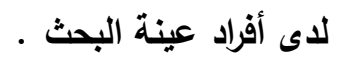
r. وجود فروق دالـة إحصـائياً بين الاختبارين القبلي والبعدي في تطوير السرعة القصوى والقوة

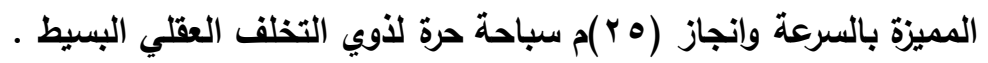

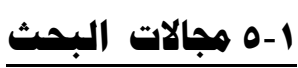




\section{هبلة كلية التزبية الرياضية .... جامهة بغداد .... المبلد r. ..... العدد ا}

1-ه - المجال البشري : عينة من لاعبي المنتخب الوطني للسباحة من ذوي التخلف العقلي البسيط عددهم (0) مباحين

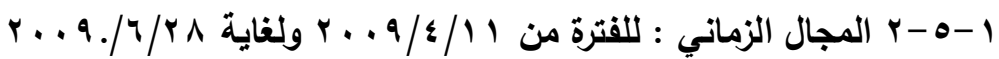

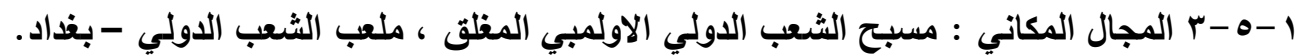

\section{البـــاب الثانـي}

ب r الدراسات النظرية

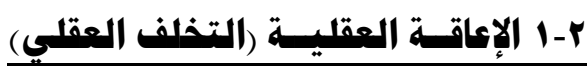

أن مصطلح الإعاقة ارتبط في أذهان الكثيرين بالتوقف عن النمو والعجز الكامل عن التعلم ولا يعكس ذلك حقيقة الأداء بقر ما يعكس سلبية الاتجاهات وتلني التوقعات فالإعاقة لا تعني التهاية ولات التاني

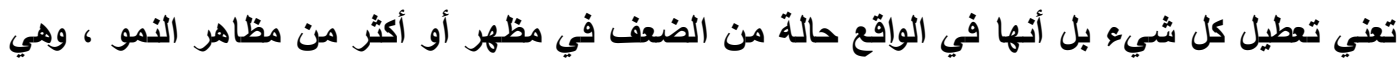

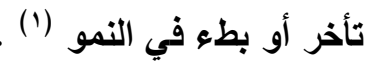
وقد عرف (حلمي ابراهيم ، ليلى السيد فرحات ، 991 19) التخلف العقلي بأنه " عدم قدرة الفرد

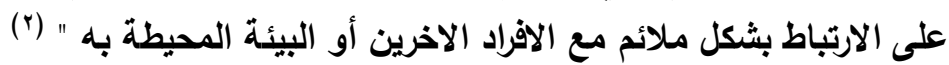

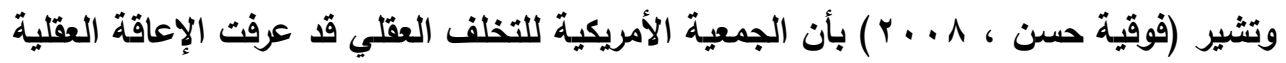

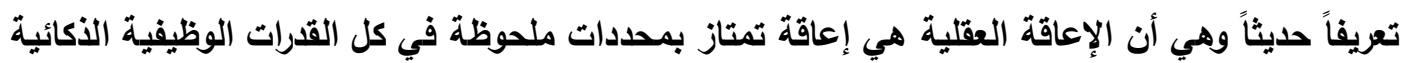

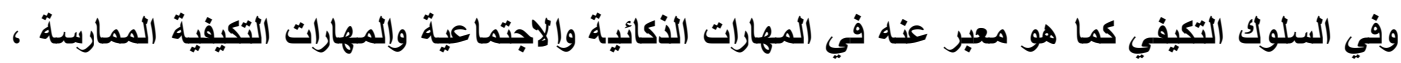

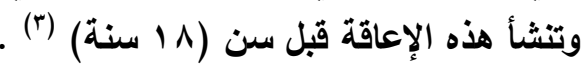

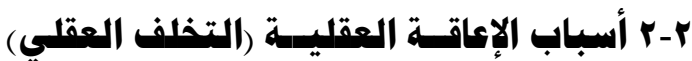

أبرزت الدراسات والبحوث المختلفة وجود وجهات نظر متعددة بين العلماء العاء عند تحديدهم للعوامل المسبية للإعاقة العقلية ، ويذكر كل من (Gannet , 2009) و (Whelley \& others , 2008) بأن "

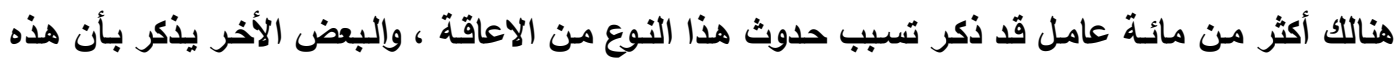

(1) ابتهاج ناجي كريم ؛ تأثير منهج تعليمي تلريبي مقترح في بعض المهارات الأساسية والقدرات الفسيولوجية بالكرة الطائرة

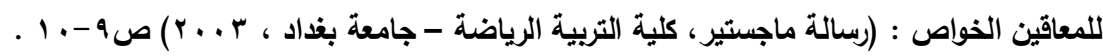

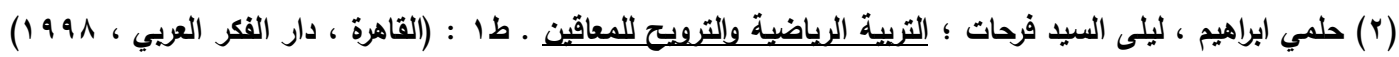
صגוץ.

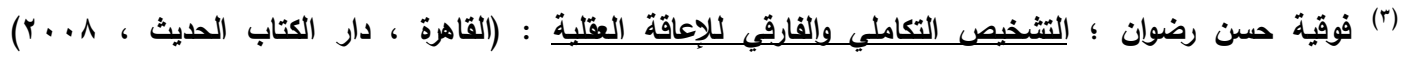
صVI. 


\section{هبلة كلية التربية الرياضية .... جاهعة بغداد ..... المبلد rr..... العدد I}

العوامل تعد مسئولة فقط بنسبة ه † \% من حالات الإعاقة العقلية التي يمكن تميزها ، ولا أحد يعرف العدد

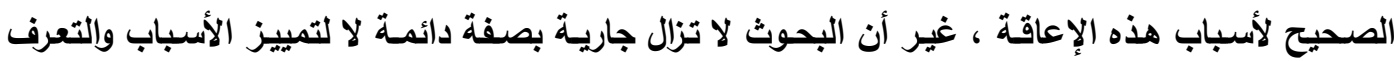

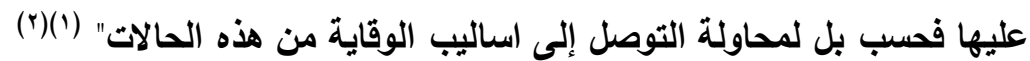

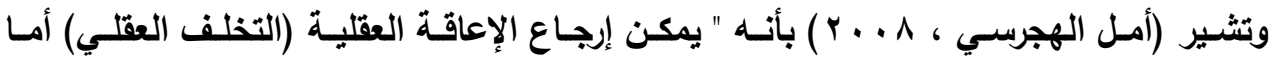

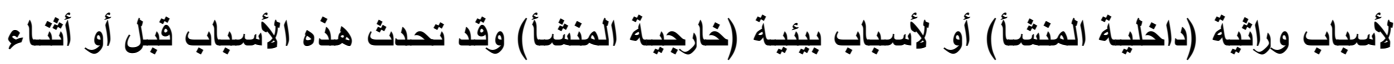

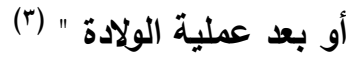

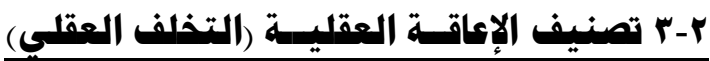

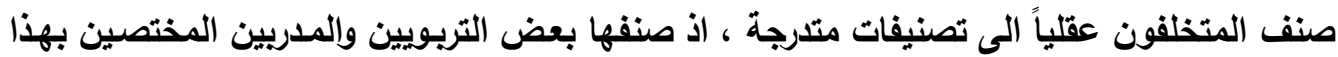

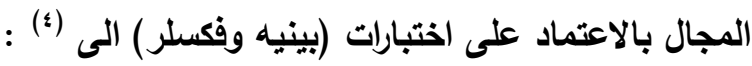

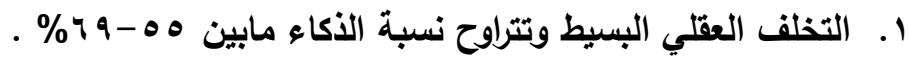

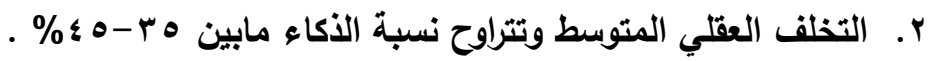

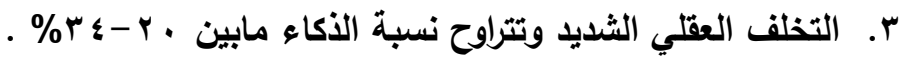

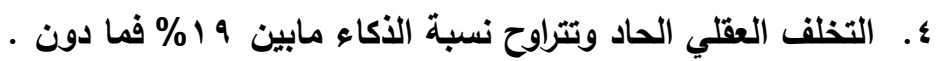

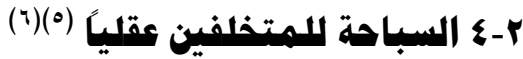

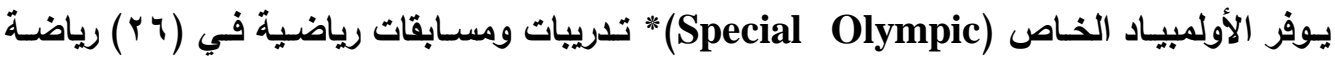

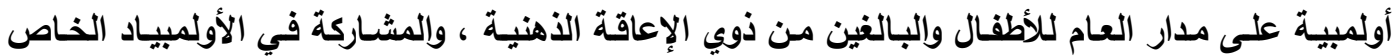

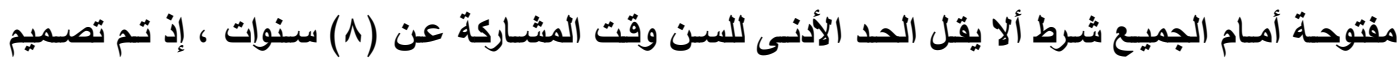

(1) Gannet H. ; Classification and etiological factors in mental retardation : (Journal of the American Collage of mental retardation, vol. 124, 2009) P.P. 26-30 .

(2) Whelley K. \& others ; Families of young adults with mental retardation transitioning into adult services $~_{2}{ }^{\text {nd }} \mathrm{Ed}:(\mathrm{USA}$, library of congress cataloging , 2008) P. 64 .

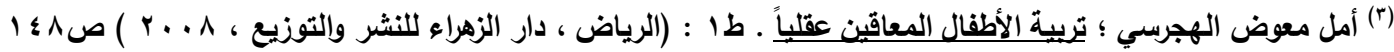

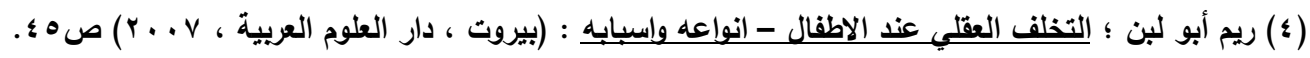

(5) http//www.somena.org/2009 .

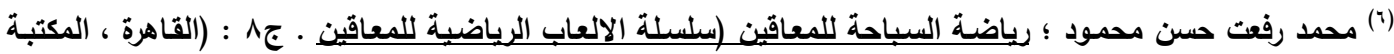

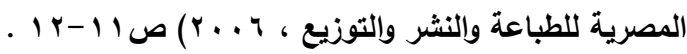

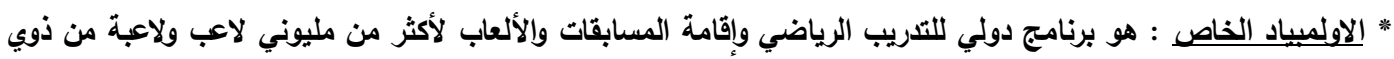

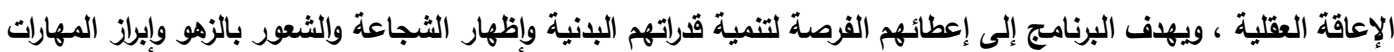

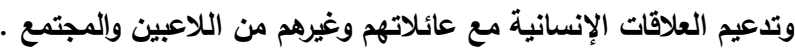




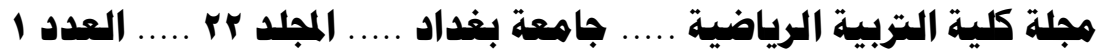

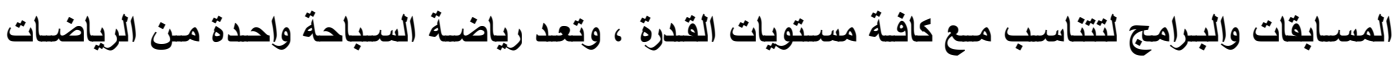

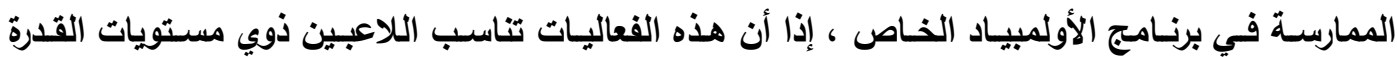

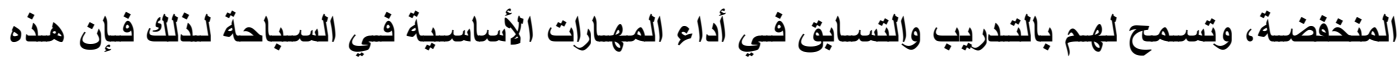

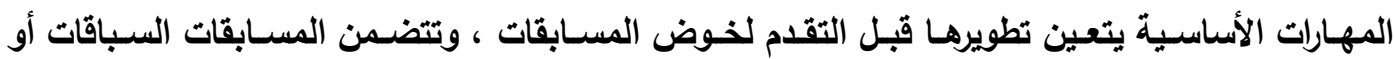
فعاليات السباحة التالية :

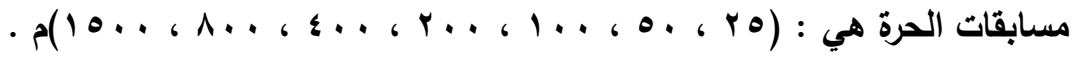

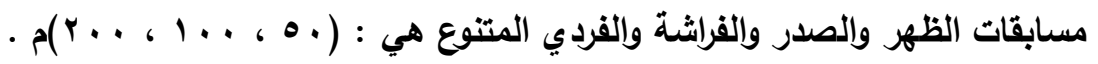

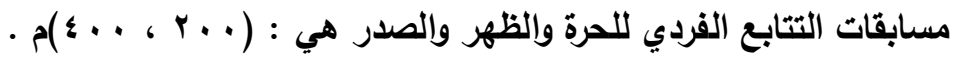

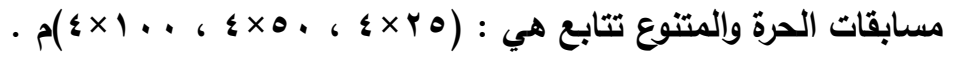

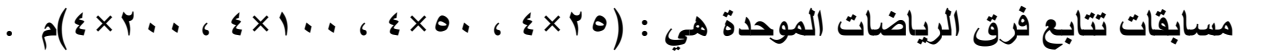

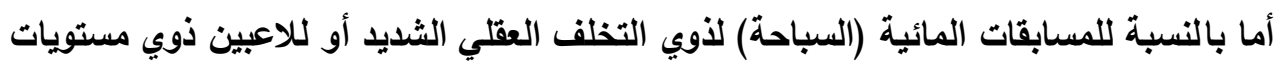

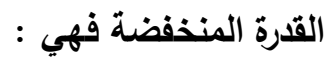

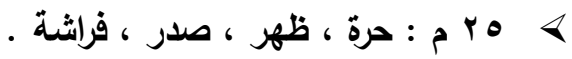

$$
\begin{aligned}
& \text { • } 10
\end{aligned}
$$

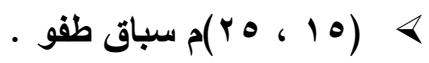

$$
\begin{aligned}
& \text { ه م م مباحة بمساعدة . }
\end{aligned}
$$

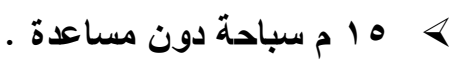

\section{ب-0 تمارين على اليابسة}

إن العمل على الارض في شروط البيئة الطبيعية والتي تثـغل أمساكن معلومـة في عملية التدريب

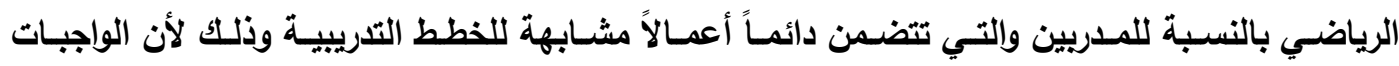
التدريبية الاساسية هي التي تساعد على حل مشاكل اللاعبين الذين يقومون بأعمال تنافسية في أمساكن

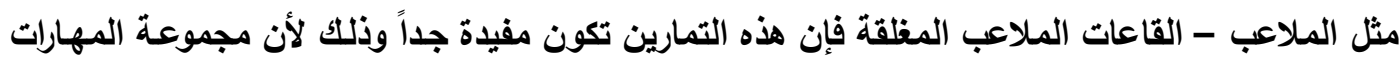
الحركية الواسعة المعدة مسبقاً تسمح بسرعة إعادة القدرات على العمل من خلال تأثيرها على اللاعبين

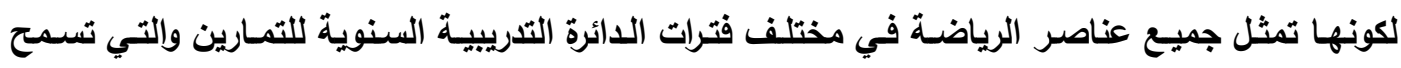




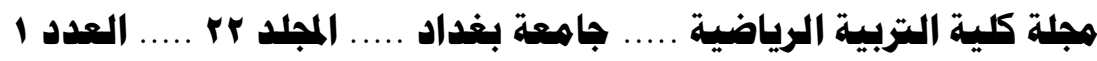

بتطوير (القوة والسرعة والقوة المميزة بالسرعة وقوة التحمل والرشاقة والمرونة) وكذلك تسمح بالابتعاد عن

حالة الملل عند إعداد اللاعبين (').

\section{r-7 تهارين في الملاد}

تعد هذه التمارين مفيدة جداً لمختلف انواع الرياضة على الرغم من قلـة استخدامها إذ من النادر ما نجد وحدات تدريبية تتضمن هذه التمارين ، ويمكن تنفيذها في البحيرات والانهار وكذلك في المسابح

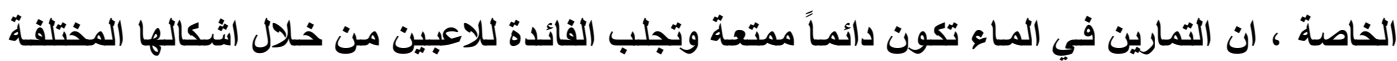
في العمليـة التدريبيـة وكثير مـن الاختصاصين يوصـون بتمـارين المـاء مـن اجل تحسين اللياقـة البانيـة

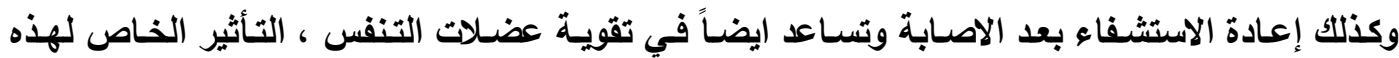
التمـارين يظهر في الالعـاب الرياضية وإلحركية في المـاء مـن خـلال جذب المتعـة للاعبين مـع التأثيرات

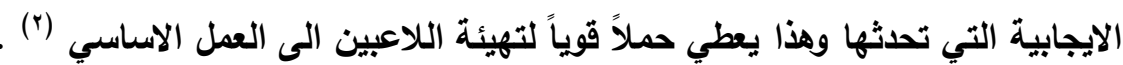

\section{البــاب الثالهــث}

r- هنهمية البمث وإجراءاته الميدانية

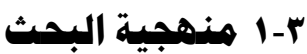

استخدمت الباحثـة المـهنج التجريبـي ذا المجموعة الواحدة للاختبـار القبلـي والبعدي لملائمتهـا مشكلة البحث .

r-r عينة البمث ذوي التخلف العقلي البسيط البالغ عددهم (0) سباحين بعمر زمني يتراوح ( ع - - 1 ) سنة امـا عمرهم العقلي فيتراوح ( • 1 - I ) سنة وحسب التصنيف المقر من وزارة العمل والشـؤون الاجتماعية ، وقد تـم وضعهم بمجموعة تجريبية واحدة .

(1) انا اسكارود يموفا (ترجمة) هاشم ياسر حسن ؛ الموسيوعة التطبقيـة للالعاب الرياضية · جץ .طا : (القاهرة ، مركز

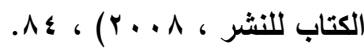

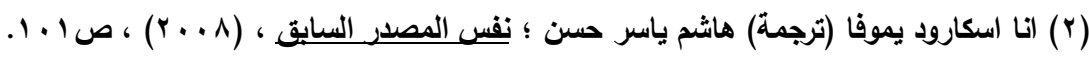




\section{هبلة كلية التربية الرياضية .... جاهعة بغداد ..... المبلد r. ..... العدد I}

ولغرض التعرف على تجانس العينة قامت الباحثة بأيجاد معامل الالتواء في قدرة القوة المميزة

بالسرعة والإنجاز وتم التوصل الى ان جميع أفراد العينـة كانوا متجانسين لأن نتائجهم كانت محصورة بين

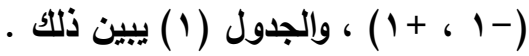

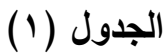

يبين تجانس عينة البحث في المتفيرات قيل البحث

\begin{tabular}{|c|c|c|c|c|c|}
\hline 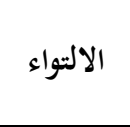 & الانحراف & الوسيط & الحسط الوسط & و القياس & المتغيرات \\
\hline$. .17 \cdot-$ & $\cdot \Lambda \cdot \varepsilon$ & YY.\&\&. & rY.r. & 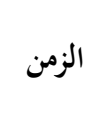 & السرعة القصوى لعضلات الرجلين والذراعين \\
\hline$\cdot . \varepsilon \cdot 0-$ & $1.1 \leq$. & ^.... & V. . . & النكرار & 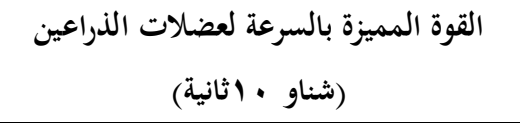 \\
\hline $.011-$ & $1.7 \varepsilon r$ & ro.... & Y $\{., \ldots$ & المسافة & 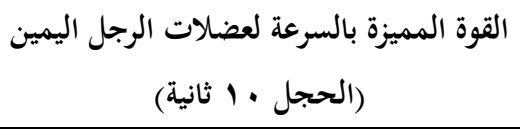 \\
\hline . rqV- & $1.11 \mathrm{~V}$ & $r \varepsilon \ldots$ & rT. . . & المسافة & القوة المميزة بالسرعة لعضلات الرجل اليسار \\
\hline. $.0 \wedge$ & $\cdot \varepsilon$. & $\leqslant V .90$. & $\varepsilon \wedge .+\neg \varepsilon$ & 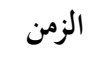 & الانجاز (السباحة لمسافة هץ متر) \\
\hline
\end{tabular}

r-r وسائل جسمع المعلومهات والادوات والاجهرة المستخدهة في البحث

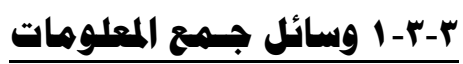

المصادر والمراجع العربية والاجنبية وشبكة المعلومات الدولية ، الملاحظة وإلتجريب .

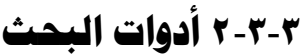

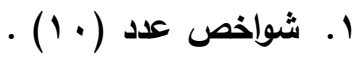

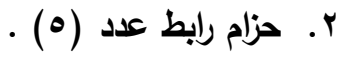

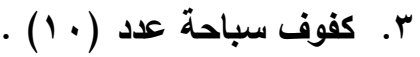

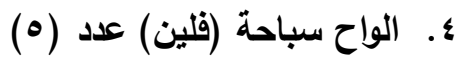

ه. كرات طبية مختلفة الأوزان . 


\section{هجلة كلية التربية الرياضية .... جاهعة بغداد .... المبلد r ..... العدد I}

7. اطواق رملية رجل ويد مختلفة الاوزان . - V

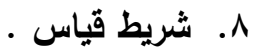

9. شريط لاصث . لونق

r-r-r الأجهزة المستخد هة في البحث

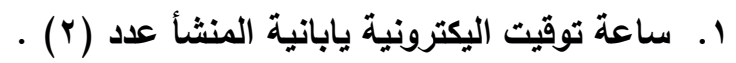

r. كاميرا تصوير فديو نوع (SONY) ياباني المنشأ . r. حاسبة يدوية نوع (CASIO) ياباني المنشأ . ع. حاسبة الكترونية (لاب توب) P4 من شركة Dell ايرلندي المنشأ .

\section{r-צ تحديد القدرات والاختبارات البدنية}

بعد ان حددت الباحثة بالاعتماد على المصادر المراجع والكتب العلمية قدرة القوة المميزة بالسرعة لعضلات الرجلين والذراعين فضلاً عن الانجاز ، قامت الباحثة أيضاً بتحديد أهم الاختبارات

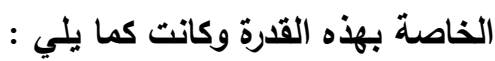

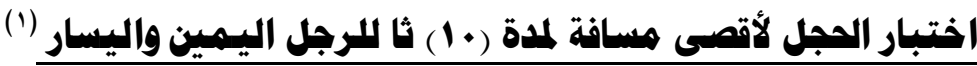

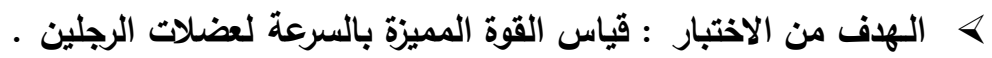

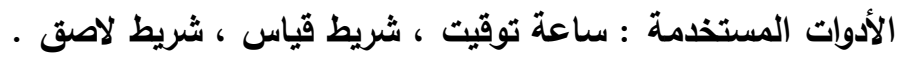
وصف الأداء : يقف المختبر على خط البلاية خلف الثريط اللاصق وعلى الرجل اليمين مـع رفع لاديط

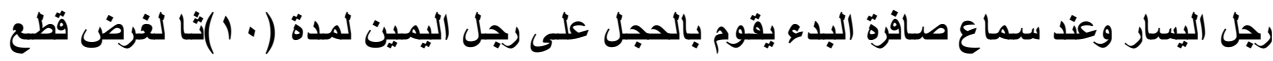

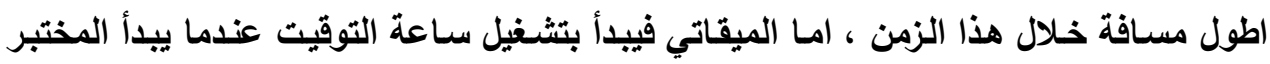

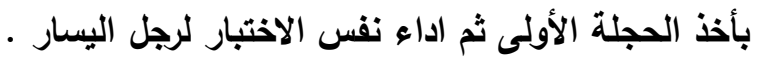

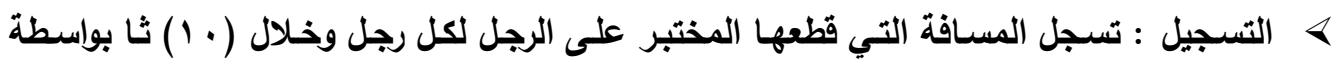
شريط القياس . ش

(1) خولة ابراهيم محيل ؛ بناء وتقنين بطارية اختبار بدنية ووظيفية بألعاب القوى لذوي التخلف العقلي البسيط (اطروحة

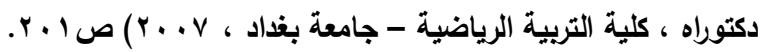


اختبار الاستناد الأهاهي على اليدين (شناو) لمدة ( الها ثا (1)

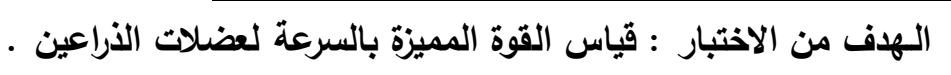

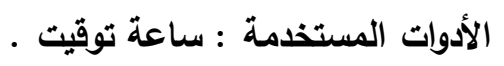

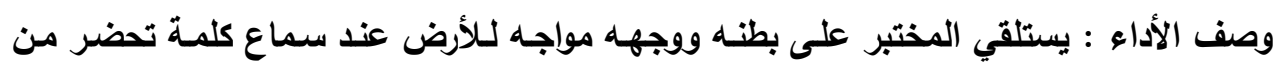

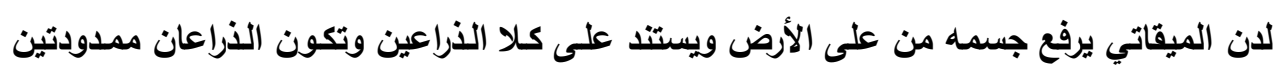

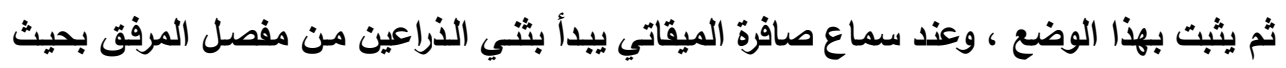

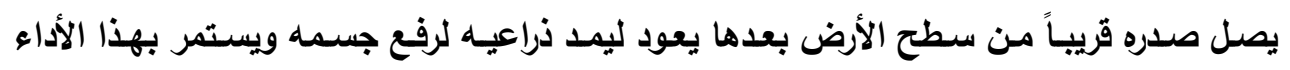

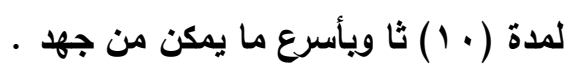
التسجيل : يعطى لكل مختبر محاولة وإحدة وتسجل عدد التكرارات لثي ومد الأراعين .

\section{(r) اختبار سباحة حرة لمسافة (10)}

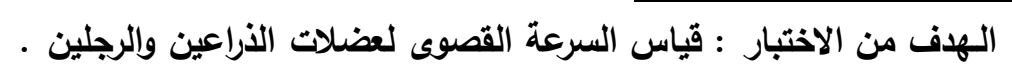

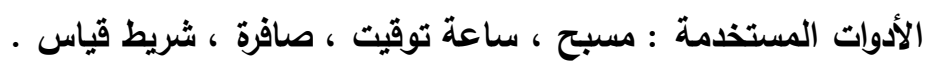

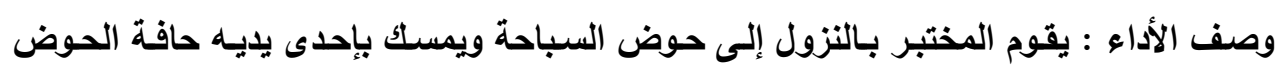

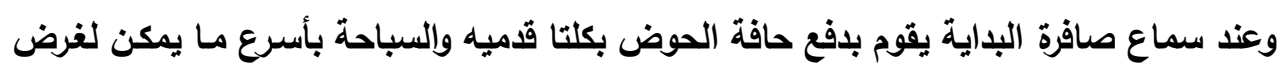

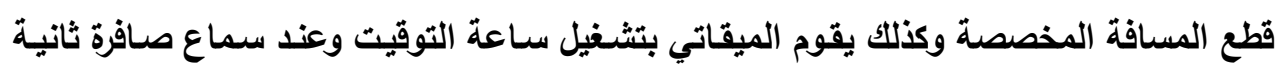

معناه قد اجتاز خط نهاية المسافة المحددة عندها يقوم الميقاتي بإيقاف ساعة التوقيت . التسجيل : يعطى لكل مختبر محاولة واحدة ويسجل الزمن الذي استغرقه لقطع مسافة الاختبار

\section{اختبار السباحة لمسافة (ro) م إنهاز (ro)}

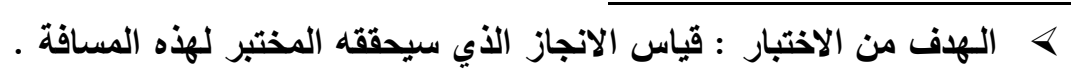

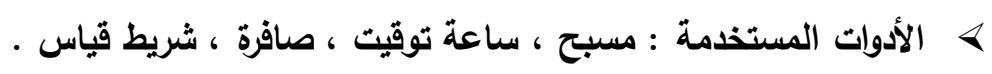

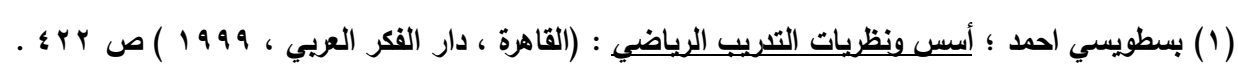

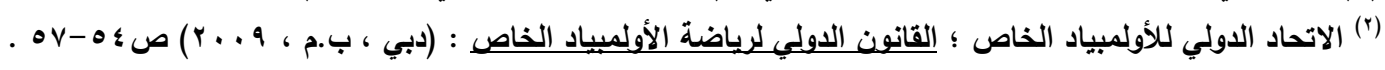

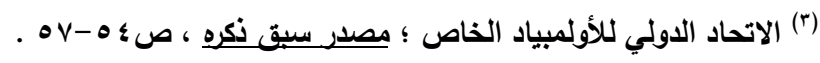


وصف الأداء : يقوم المختبر بـالنزول إلى حوض السباحة ويمسك بإحدى يايـه حافة الحوض

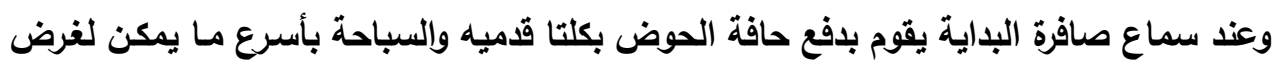

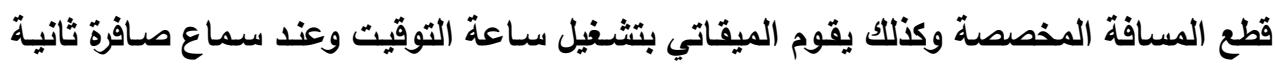

معناه قد اجتاز خط نهاية المسافة المحددة عندها يقوم الميقاتي بإيقاف ساعة التوقيت . ه التسجيل : يعطى لكل مختبر محاولة واحدة ويسجل الزمن الذي استغرقه لقطع مسافة الاختبار

\section{r-ه التجربة الاستطلاعية}

قامت الباحثة بـأجراء التجربـة الاستطلاعية على عينة من عينـة التجربـة الرئيسية نفسـها تتألف من

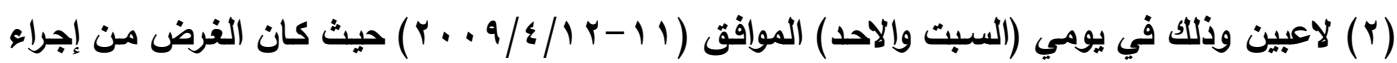
هذه التجربة هو :

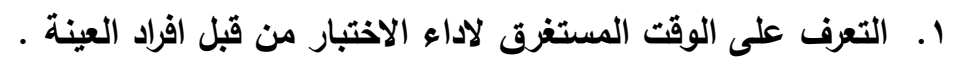

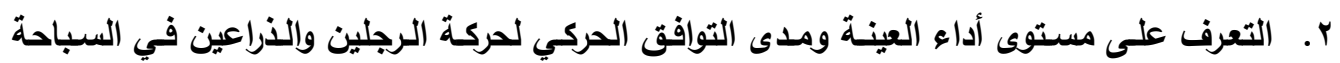
الحرة .

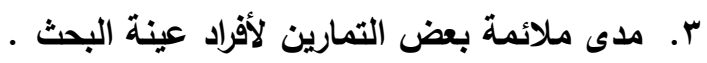

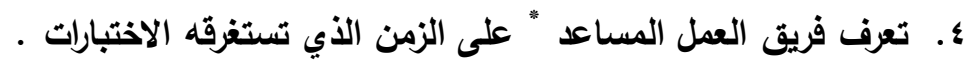

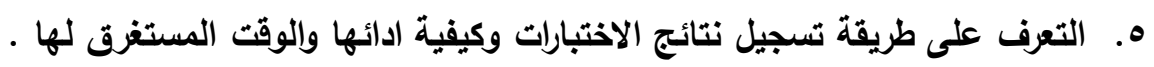

r-7 الاختبارات القبـية

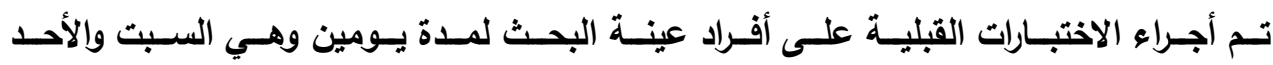

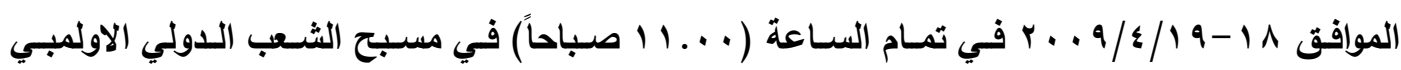

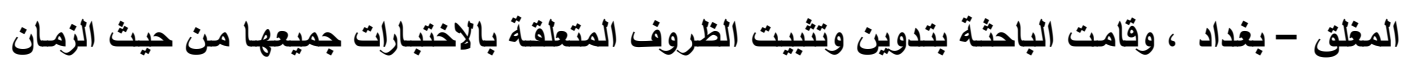

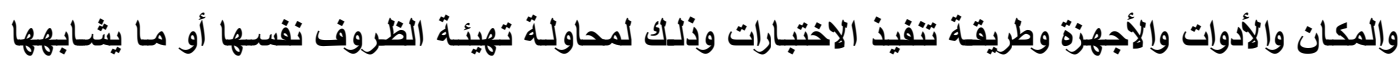
عند أجراء الاختبارات البعدية ، وقد وزعت الاختبارات على اليومين وكما يلي : اختبار اليوم الأول : الأبارت

1. اختبار السرعة القصوى لعضلات الرجلين والأراعين (سباحة (ه ام) حرة .

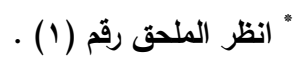




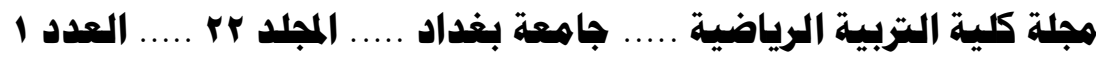

r. اختبار القوة المميزة بالسرعة لعضـلات الرجلين (الحجل على الرجل اليمين واليسـار لمدة ( • )

r. اختبار القوة المميزة بالسـرعة لعضـلات الذراعين (الاستتاد الأمسامي على اليدين (شنـاو) لمـدة

اختبار اليوم الثاني : (الثي

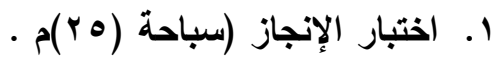

التجربة الرئيسة (تنفيذ التمرينات المتنوعة V-r

قامت الباحثة بوضع مجموعة من التمارين المتنوعة * تطبق داخل حوض السباحة (في الماء) وتمارين أخرى تطبق خارج حوض السباحة (على اليابسة) وقد راعت الباحثة القدرات البذنية لإفراد عينة البحث عند وضع هذه التمارين وكما يأتي :

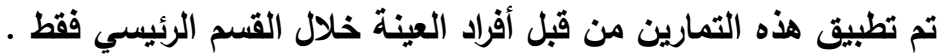

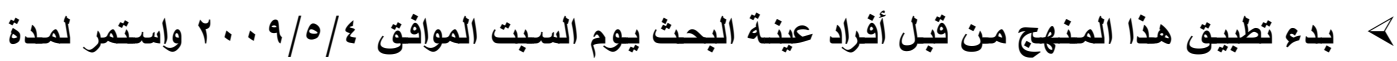

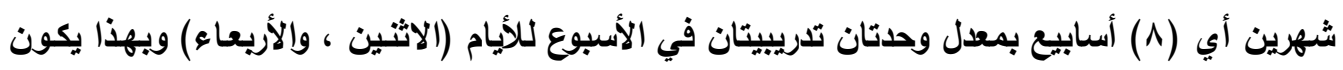
مجموع الوحدات التدريبية (؟ آ ) وحدة.

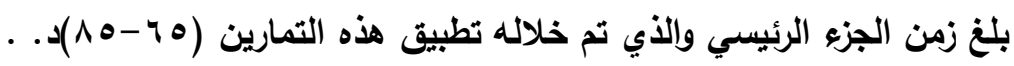

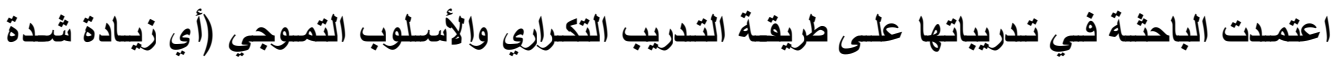

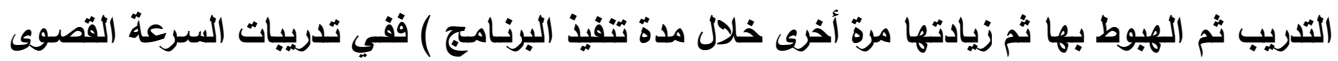

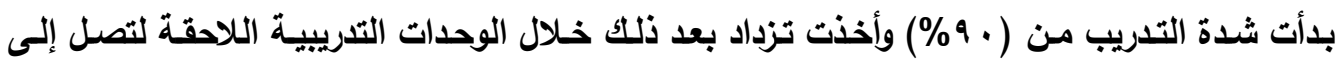

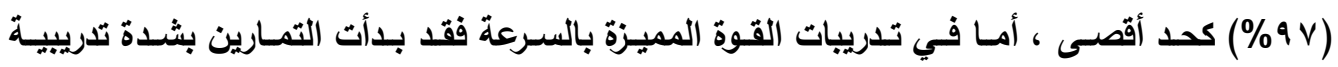

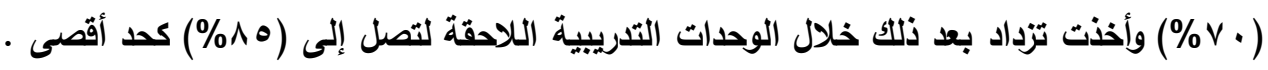
نظراً لخصوصية العينة كونهم من ذوي التخلف العقلي البسيط ولعدم إمكانيتهم في بعض الأحيان فهم

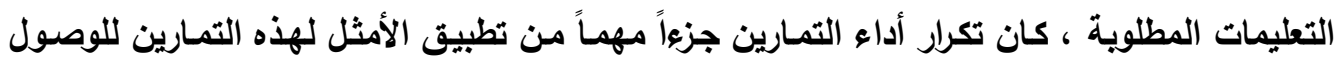

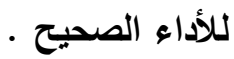

" انظر الملدق رقم (r) 
استخدمت الباحثة عند تنفيذها التمارين المتنوعة سواء كاتت داخل الماء أو على اليابسة مجموعة

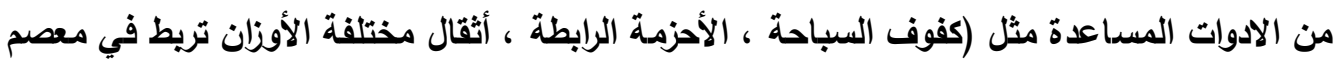

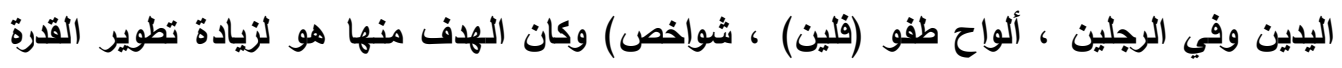

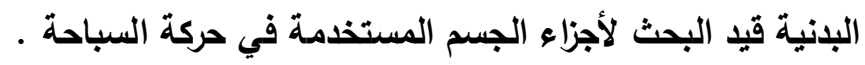

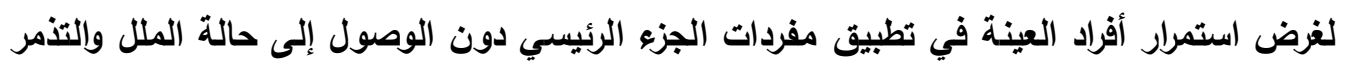

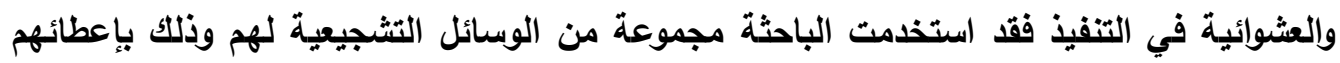
هدايا والألعاب مختلفة لغرض تحفيزهم وذلك بسبب الصعويات التي واجهتها الباحثة في بداية تنفيذ التجربة هدابة والعابة

قسمت الباحثة القدرات البدنية قيد البحث بالاعتماد على المصادر العلمية لأدبيات علم التدريب

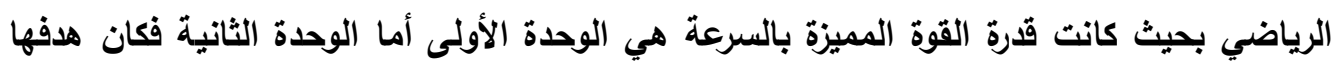

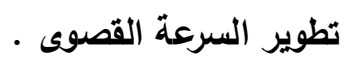

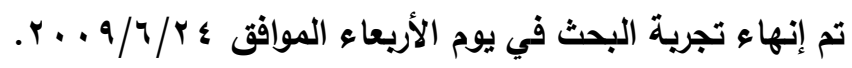

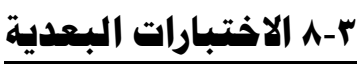

بعد أن أكملت عينـة البحث جميع الوحدات التريبيـة ضمن منهجهم التدريبي المعد من قبـل

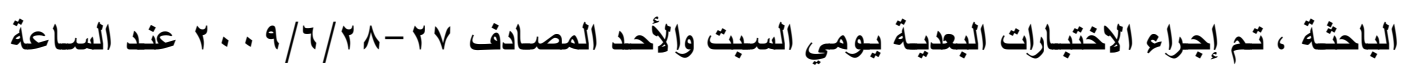

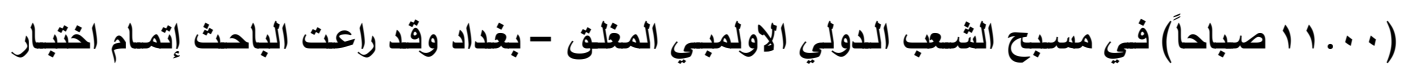
القدرات البذنية جميعها وفي الظروف نفسها التي جرت فيها الاختبارات القبلية . ل

r-9 الوسائل الإهصائية

اعتمدت الباحثة على البرنـامج الإحصائي الـ (SPSS) لاستخراج النتائج ، وكانت هذه الوسائل

1. الوسط الحسابي .

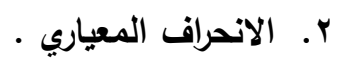

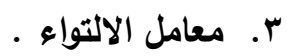

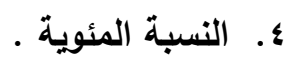

ه. ت تلعينات المستقلة .

צ. قانون نسبة التطور . 


\section{هبلة كلية التربية الرياضية .... جاهعة بغداد ..... المبلد r...... العدد ا....}

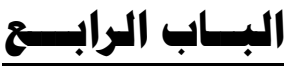

ع- عرض النتائج وتهليلها وهناقشتاها

تضمن هذا الباب عرض نتائج كل من الاختبارات القبلية والبعدية لعينة البحث وتحليلها ، كما تم

وضع النتائج في جداول واشكال بيانية تسهل ملاحظة الفرق والمقارنة بينها وصولاً الى النتائج النهائية ،

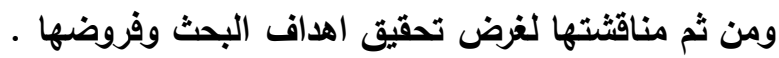

ع- 1 عرض نتائج اختبار القوة المميرة بالسرعة لهضلات الرجلين والذراعين وتهليلها

ومناقشتهما

ع- ا- 1 عرض نتائج الوسط الصسابي والانــراف المعياري في الاختبارين القبلي والبعدي في

اختبار القوة المميزة بالسرعة لعضلات الرجلين (الرجل اليمين واليسار) وعضلات الذراعين

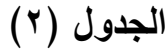

يبين الوسط الحسابي والانحراف المعياري في الاختبارين القبلي والبعدي لاختبار القوة المميزة بالسرعة لعضلات الرجلين والذراعين

\begin{tabular}{|c|c|c|c|c|c|}
\hline \multicolumn{2}{|c|}{ الاختبار البعدي } & \multicolumn{2}{|c|}{ الاختبار القبلي } & \multirow{2}{*}{ القياس } & \multirow{2}{*}{ القدرة / الاختبار } \\
\hline$\varepsilon$ & سنَ سن & $\varepsilon$ & سَن & & \\
\hline $1.9 r \varepsilon$ & rq.A.. & $1.7 \leq \mu$ & $r \varepsilon . r \ldots$ & المتر & (القجوة المميزة بالسـرعة لعضــلات الرجل اليمسين \\
\hline Y.7. 1 & rq. ... & $1 . \wedge 1 \mathrm{~V}$ & rr. . . & المتر & 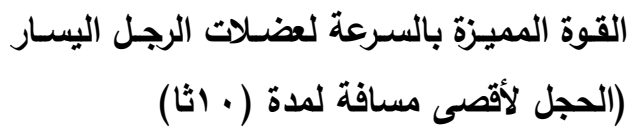 \\
\hline . . $A r V$ & q.r.. & $1.1 \varepsilon$. & V. . . & تكرار & 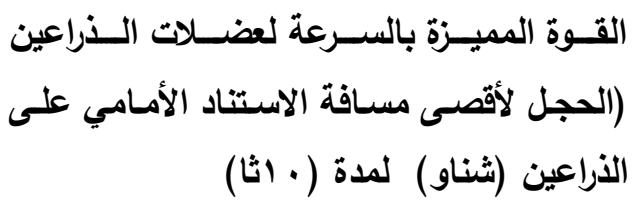 \\
\hline
\end{tabular}

من خـلال عرض الجدول (r ) نشـاهد بأن قيمـة الوسط الحسـابي في الاختبار القبلـي لعضـلات

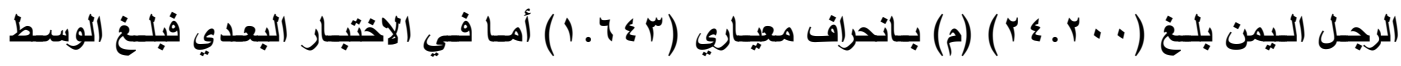

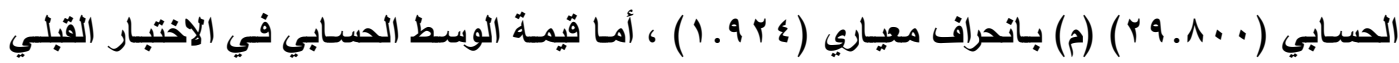

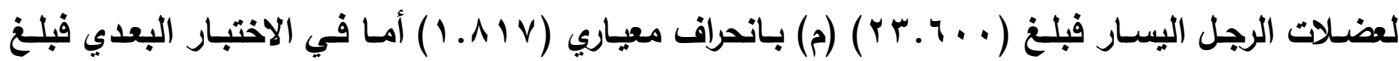




\section{هبلة كلية التربية الرياضية .... جاهعة بغداد ..... المبلد r...... العدد I}

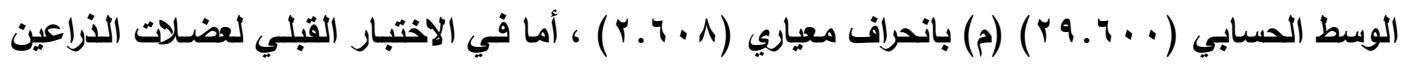

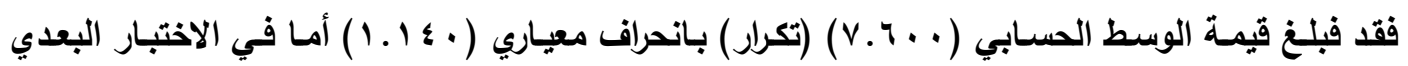

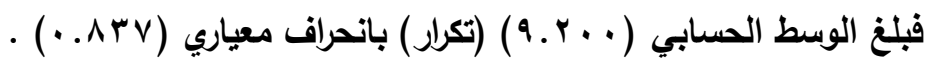

ع- ا - r عرض نتائج فرق الوسط الـمسابي والانحراف المعياري للفروق وقيسمة (T) المسوبة

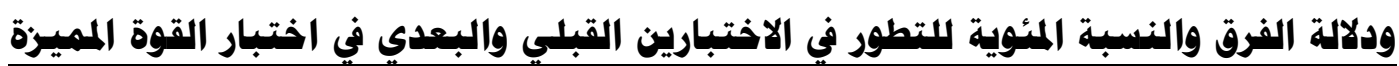
بالسرعة لعضلات الرجلين (الرجل اليمين واليسار) وغضلات الذراعين وتمليلها .

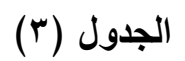

يبين فرق الوسط الحسابي والانحراف المعياري للفروق وقيمة (T) المحسوية ودلالة الفرق والنسبة المئوية للتطور في الاختبارين القبلي والبعدي لاختبار القوة المميزة بالسرعة لعضلات الرجلين والذراعين

\begin{tabular}{|c|c|c|c|c|c|c|}
\hline التطور \% نسبة & الفرق & مستوى الخطأ & قالمحسوية & ع ف & فَنَ & القدرة / الاختبار \\
\hline rr.ls. & معنوي & $\cdots \varepsilon$ & $7 .+49$ & $Y . . V \varepsilon$ & $0.7 \ldots$ & 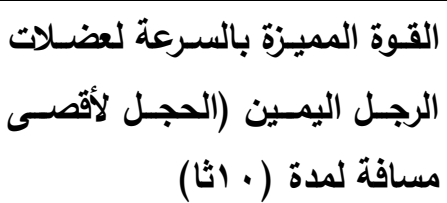 \\
\hline Yo. $\{Y \varepsilon$ & معنوي & $\cdots 11$ & $\varepsilon . \varepsilon V Y$ & r.... & $7 \ldots$ & 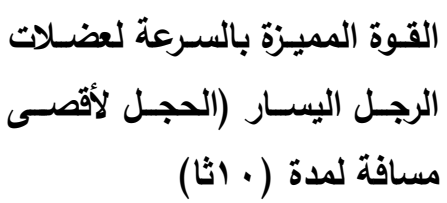 \\
\hline r 1...or & معنوي &. .17 & $\varepsilon \ldots$ & $\cdot . \wedge 9 \leq$ & $1.7 \ldots$ & الذألـوة الميـزة بالسـرعة لعضـلات \\
\hline
\end{tabular}

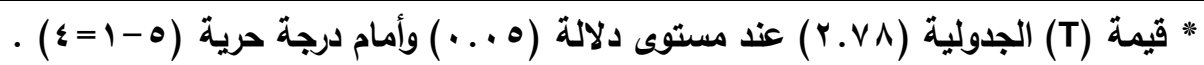

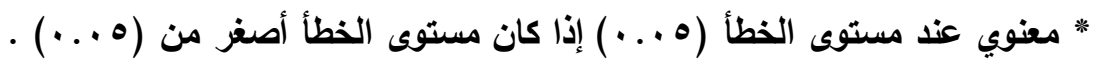

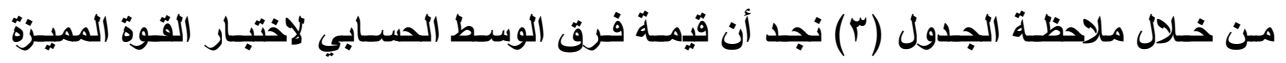

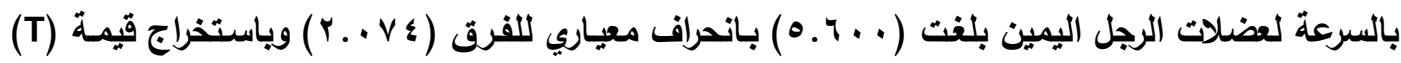

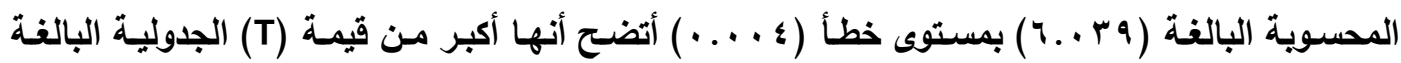




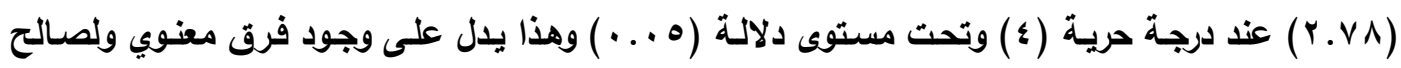

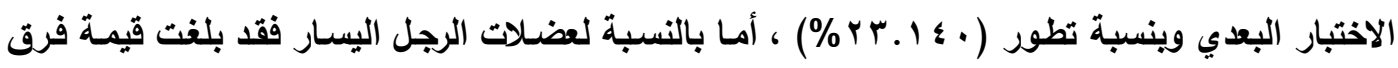

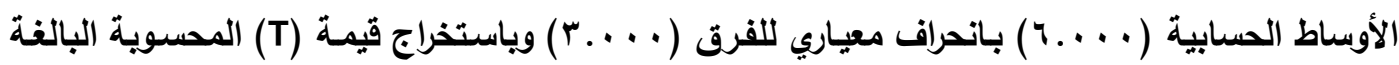

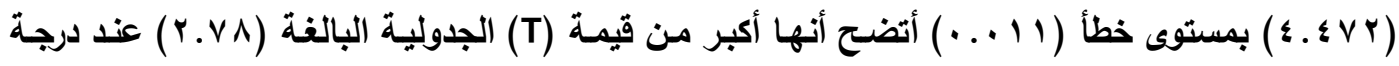

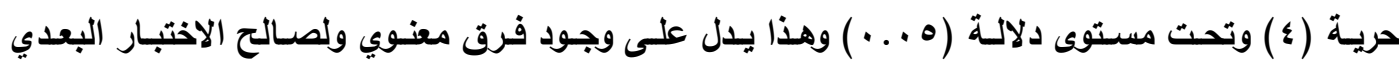

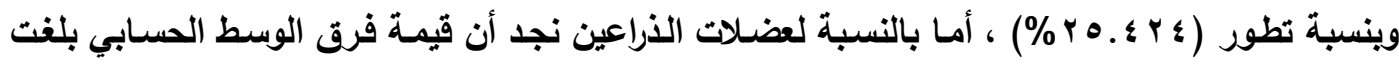

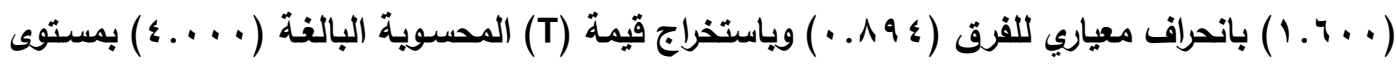

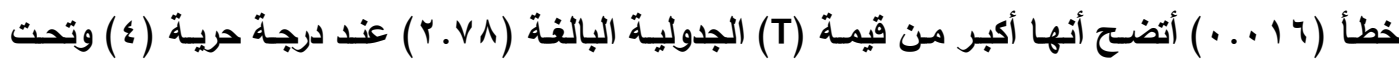

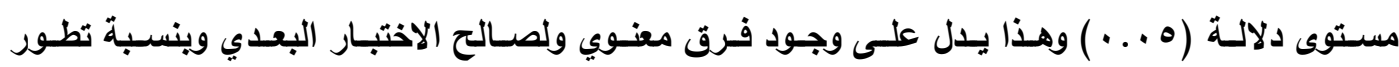

. (\% \% . . O O r )

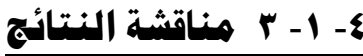

من خلال ملاحظة الجدول (r) نجد بأن دلالة الفروق كانت معنوية ولصالح الاختبار البعدي في اختبار الحجل على رجل اليمين مرة وعلى رجل اليسار مرة ثانيـة ، وتعزو الباحثة ذلك الـى ان التمرينات

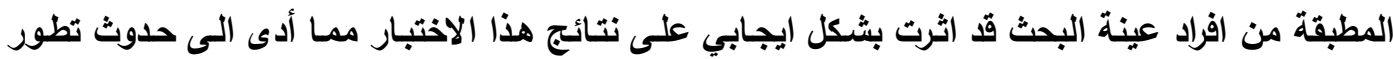

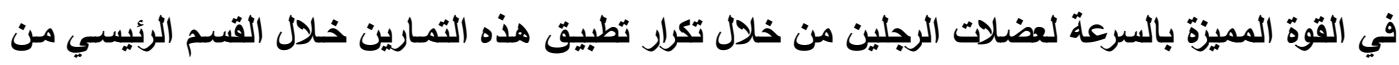
الوحدة التدريبية ويما يتلاعم مع شدة وحجم التدريب كذلك استخدام الاثقال في بعض هذه هذه التمـارين التي كانت تطبق داخل حوض السباحة فضلاً عن تطبيق بعض التمارين خارج حوض السباحة باستخدام وزن

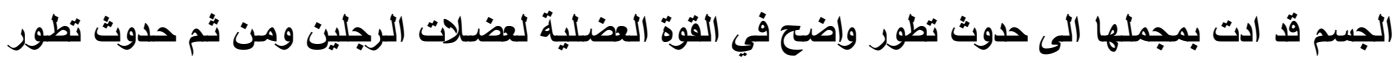

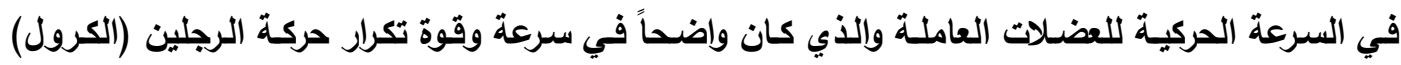

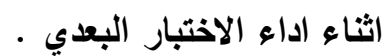

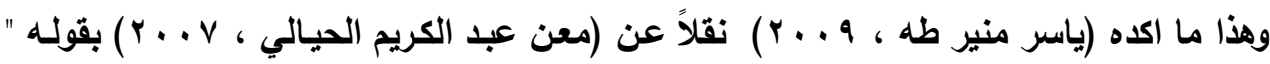

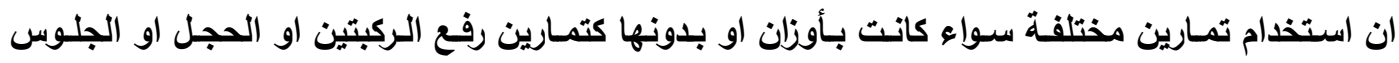
بثني الركبتين (الدبني) او القفز فوق موانـع ويشـد مناسبة وسرعة عاليـة في الاداء مـع تقتيبين فترات

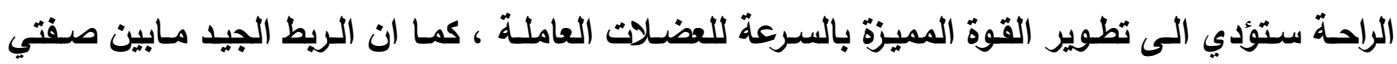




\section{هبلة كلية التربية الرياضية .... جاهعة بغداد ..... المبلد rr..... العدد I}

السرعة والقوة من خلال استخدام تمارين متنوعة ويشدد مناسبة ستؤدي الى تحقيق الهـف المنشود وهو تطوير هذه القدرة " (') . ويتفق مـع هذا الرأي (Nelso K. R. , 2007) والذي اشـار " ان القوة المميزة بالسرعة تتكون

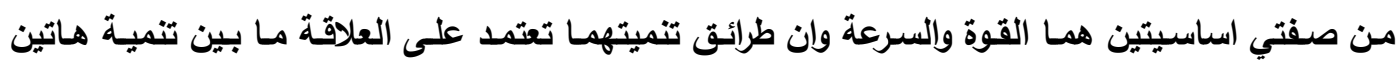

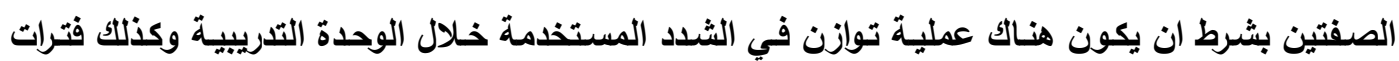

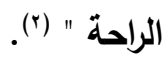

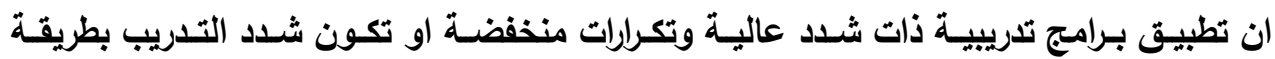

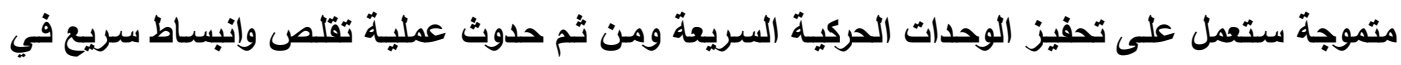

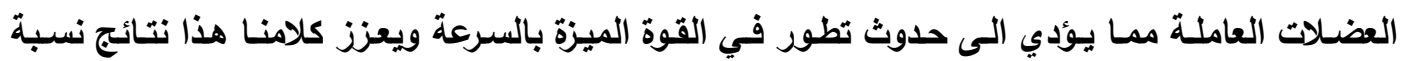

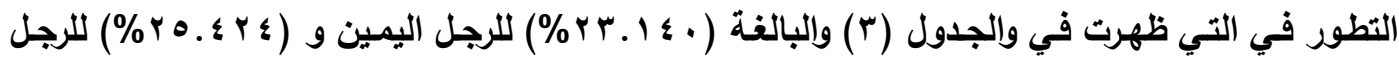

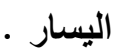

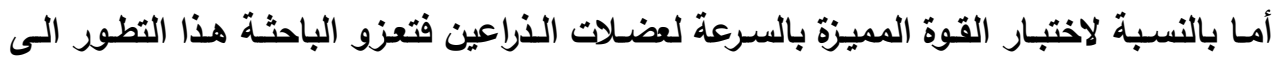

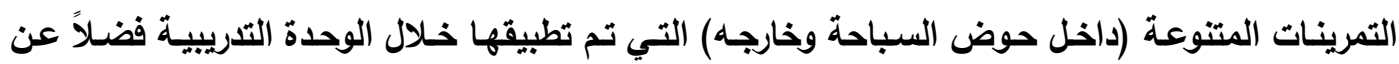

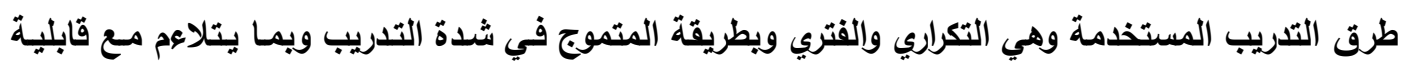

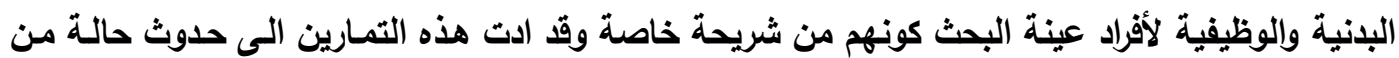

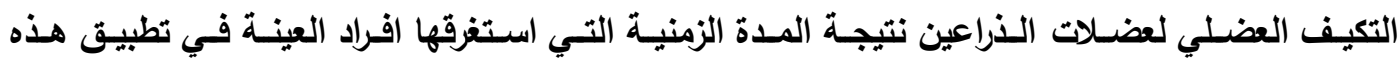
التمرينات أي حدوث حالـة من التوافق بين الالياف العضلية داخل العضلات وسرعة الانقباض للوحدات

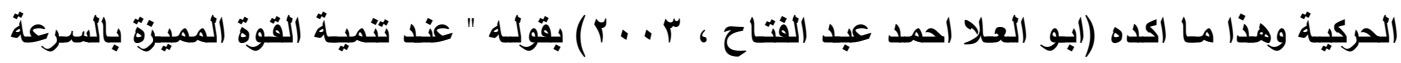

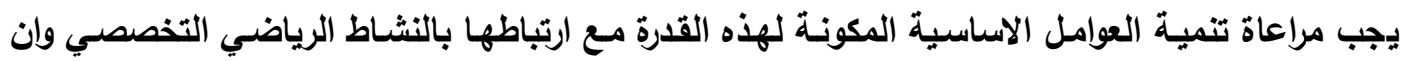
هذه العوامل الاساسية هو التوافق داخل العضلة وسرعة انقباض الوحدات الحركية " (†).

(1) ياسر منير طه علي ؛ أثر برنامج تدريبي مقترح في بعض عناصر اللياقة البذنية وعلاقتها بالمستوى الرقمي في بعض

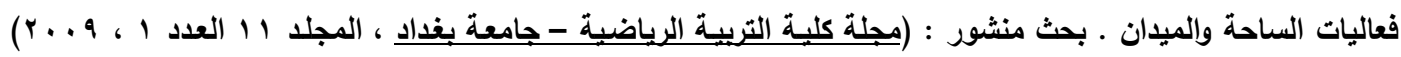
. PrV

(2) Nelson K. R. ; Training in track \& Field : (New York, Copal point publishers, 2007) P. 88 .

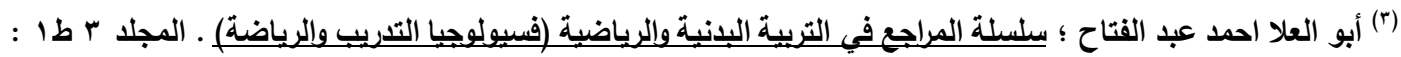

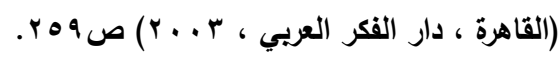




\section{هبلة كلية التربية الرياضية .... جاهعة بغداد ..... المبلد rr..... العدد I}

كذلك ان التمـارين التي كانت تطبق باستخدام الاثقال داخل حوض السباحة فضلاً عن مقاومـة الجسم للماء قد ادت الى حدوث تطور في القوة العضلية لعضـلات الذراعين ثم انعكاسـها على سرعة اداء الائي

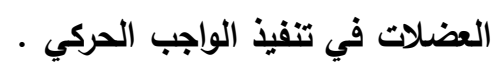
وان هنالك علاقة وطيدة بين القوة العضلية والسرعة اذ ان تنمية الأولى (القوة العضلية) تعد من

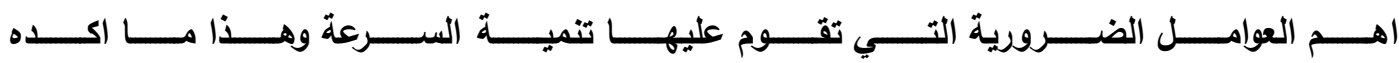
(Scott K. , Edward T. , 2008) القرات الاخرى لانها صفة موروثة تعتمد على الالياف العضلية وعلى سرعة الانقباض العضلي المرتبط بالقوة العضلية فالرياضي الذي يمتلك قوة عضلية سوف ينعكس تأثير ذلك على السرعة (سرعة الانقباض الاض

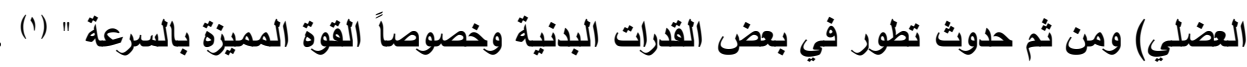

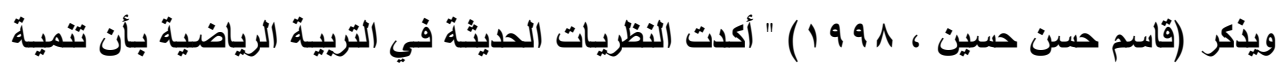
صفة السرعة والقوة في آن واحد يمكن تحقيقه بمساعدة التمـارين المركبة من السرعة والقوة او تمـارين

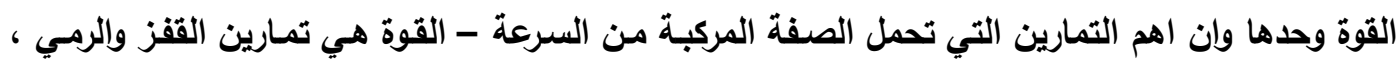

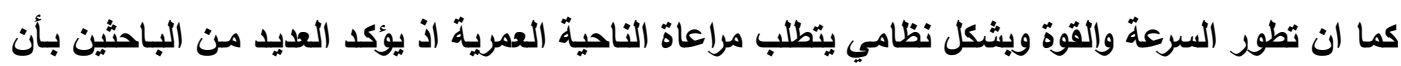

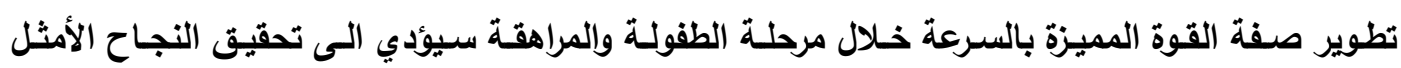

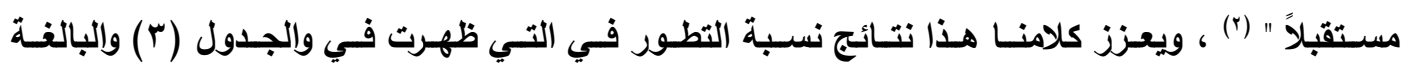
. $(\%$ Y $1.0 \%)$

(1) Scott K. Powers, Edward T. Howley ; Exercise physiology Theory and application to Fitness and performance $10^{\text {th }}$ Ed : (New York, McGraw - Hill companiespub , Inc . 2008) P.P. 110-111 .

(ץ) قاسم حسن حسين ؛ علم التدريب الرياضي في الأعمار المختلفة . طا : (القاهرة ، دار الفكر العربي ، 99 1 ) ص •9. 
البمدد | Pr المبلد جاهمة بهداد هبلة كلية التربية الرياضية

ع- r عرض نتائج اختبار السر عة القصوى لعضلات الذراعين والرجلين وتمليلها ومناقشتها. ع- r- 1 عرض نتائج الوسط الصسابي والانهراف المعياري في الاختبارين القبلي والبعدي في اختبار السرعة القصوى لعضلات الذراعين والرجلين (السباحة المافة (10 م) حرة) وتهليلها.

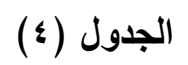

يبين الوسط الحسابي والانحراف المعياري في الاختبارين القبلي والبعدي لاختبار السرعة القصوى لعضلات

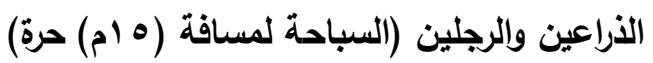

\begin{tabular}{|c|c|c|c|c|c|}
\hline \multicolumn{2}{|c|}{ الاختبار البعدي } & \multicolumn{2}{|c|}{ الاختبار القبلي } & \multirow{2}{*}{ وحدة القياس } & \multirow{2}{*}{ القدرة / الاختبار } \\
\hline$\varepsilon$ & سَن سن & $\varepsilon$ & سنَ س & & \\
\hline$\because \vee 91$ & $r \ldots r$ & $\cdot \wedge \cdot \varepsilon$ & YY.YI. & ثانية & والرجلين (السبــرعة القصـــوى لعضـــلات الــــراعين \\
\hline
\end{tabular}

الجدول ( ؛ ) يبين الوسط الحسـابي والانحراف المعياري في الاختبارين القبلي والبعدي لاختبار

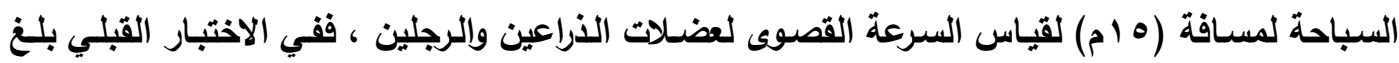

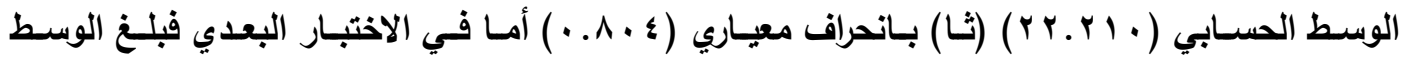

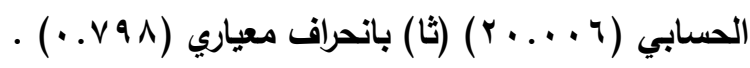

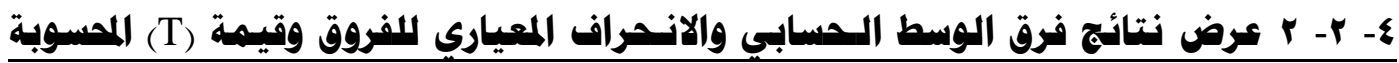
ودلالة الفرق والنسبة المئوية لاتطور في الاختبارين القبلي والبعدي في اختبار السرعة القصوى لعضلات الذراعين والرجلين (السباحة المسافة (0 امج) حرة) وتهليلها. الجدول (0)

يبين فرق الوسط الحسابي والانحراف المعياري للفروق وقيمة (T) المحسوية ودلالة الفرق وإلنسبة المئوية للتطور في الاختبارين القبلي والبعدي لاختبار السرعة القصوى لعضلات الأراعين والرجلين

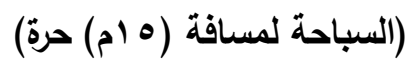

\begin{tabular}{|c|c|c|c|c|c|c|}
\hline التطور \% & الفرق & مستوى الخطأ & 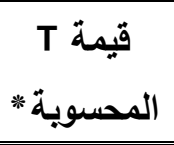 & ع ف & فََ & القدرة / الاختبار \\
\hline $9.9 r r$ & معنوي & $\cdots \cdots$ & $1 . . \wedge \bullet \wedge$ &.$\leqslant \leqslant \leqslant$ & Y.Y. $\varepsilon$ & 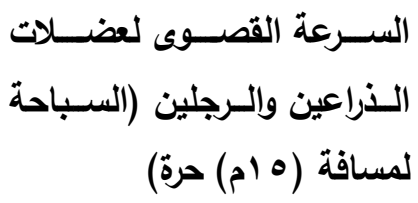 \\
\hline
\end{tabular}




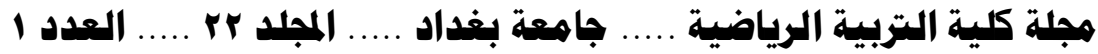

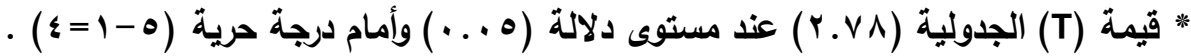

$$
\begin{aligned}
& \text { * معنوي عند مستوى الخطأ (ه .. .) إذا كان مستوى الخطأ أصغر من (ه . . . ) . }
\end{aligned}
$$

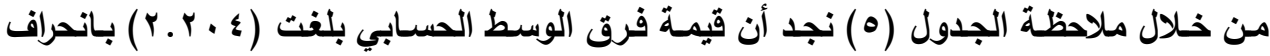

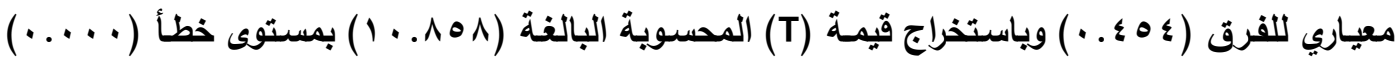

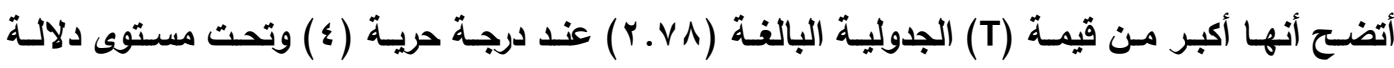

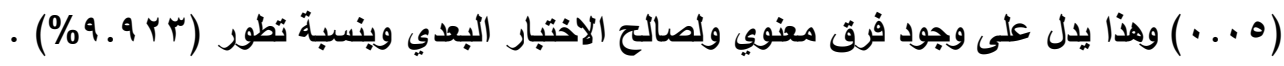

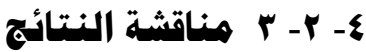

من خلال ملاحظة الجدول (ه ) نجد بأن دلالـة الفروق كاتت معنويـة ولصـالح الاختبار البعدي وتعزو الباحثة هذا التطور الـى التمـارين المتنوعـة التي تم تطبيقها مـن افراد عينـة البحث في القسـ الرئيسي خـلال الوحدة التـريبية فضـلاً عن التمـارين الاخرى التي كانت تهدف الـى تطوير القوة العضلية والتي انعكست على تطوير السرعة القصوى من خـلال الانقباض العضلي السريع للعضـلات العاملـة في العـي الذراعين والرجلين ، وان هذه الصفة (السرعة القصوى) هي من الصفات المهمـة في سباحة المسـافات

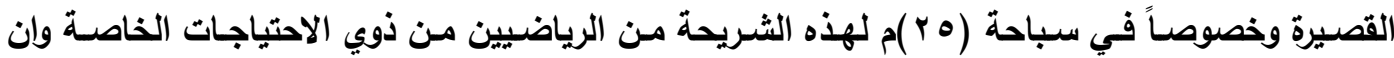

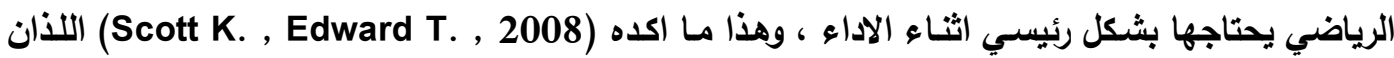
أشارا " بأن السرعة القصوى تعد من اهم العوامل في تعزيز الانتاج لسباحي المسافات القصيرة لذا يجب

منح هذه الصفة المهمة اهتماماً كبيراً في عملية التدريب الخاصة باعتبارها جوهر لتحقيق الانجاز " (1).

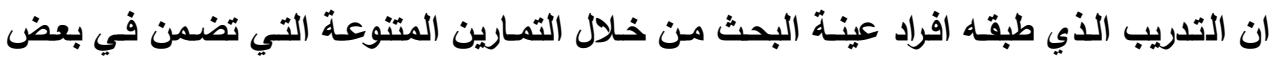

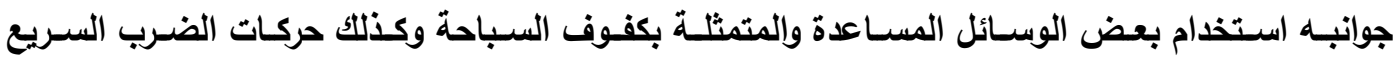
(الكرول) سواء من الثابت او المتحرك قد ادى الى حدوث تطورٍ واضِحِ في السرعة القصوى وهذا يعني

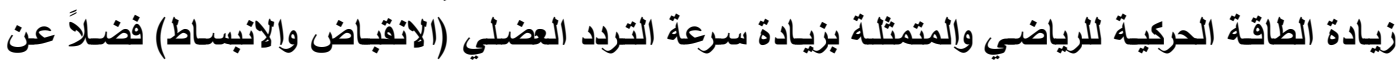

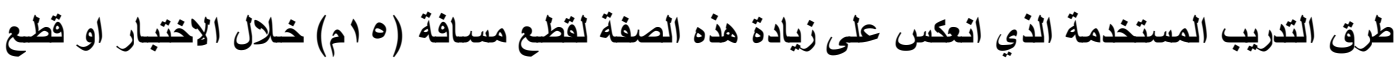

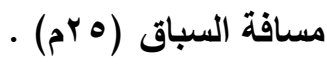

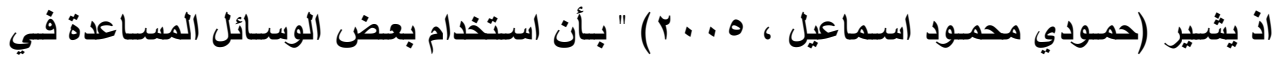
سباحة المسافات القصيرة ككفوف السباحة تعد عاملاً مهماً في تنمية القوة العضلية لدى السباح لانها

(1) Scott K. Powers, Edward T. Howley ; Opcit , 2008, P.P. 149-150 . 


\section{هبلة كلية التربية الرياضية .... جاهعة بغداد ..... المبلد r ..... العدد I. I}

ستؤدي الى زيادة القوة الدافعة للجسم وذلك عن طريق سحب كميات اكبر من المـاء ودفعها الى الخلف مما يؤدي الى سرعة تقدم الجسم للامـام خـلال المـاء وهذا سيؤدي السى تحقيق التكيف المطلوب للعضـلات

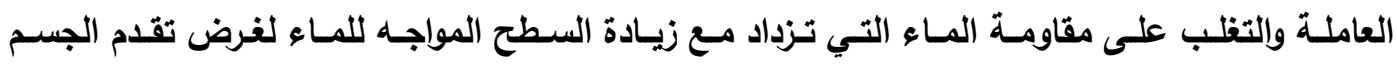

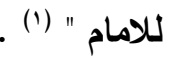
ومن خلال ما تقلم نستدل ان التدريب باستخدام وسـائل مسـاعدة ككفوف السباحة مـع الاثقال او

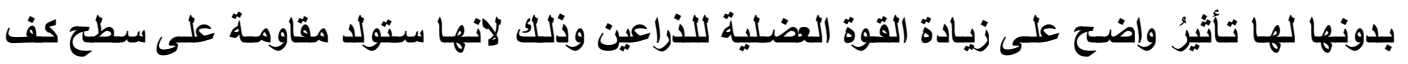
السباحة المستخدم باتجـاه سـب المـاء واللذي يـؤدي السى بـذل جهـ اكبر ممـا هو عليهـ دون استخدام

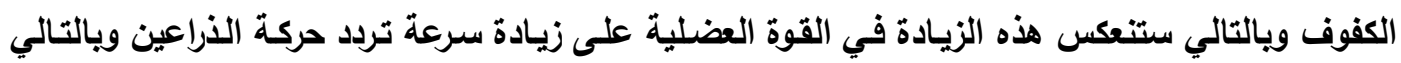

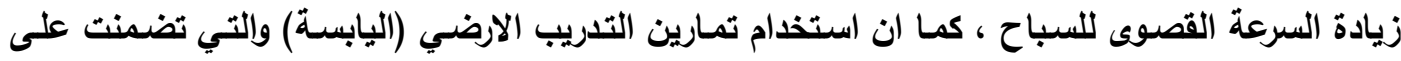

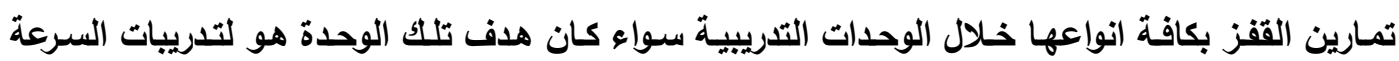

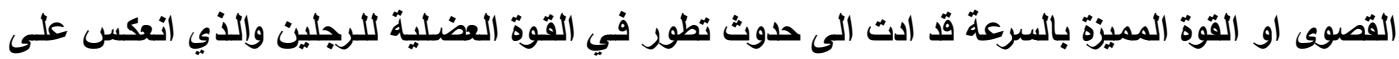
زيادة سرعة تردد حركتها ممـا سـاهت مـع حركة الذراعين في زيادة وتطور صفة السرعة القصوى لجسم

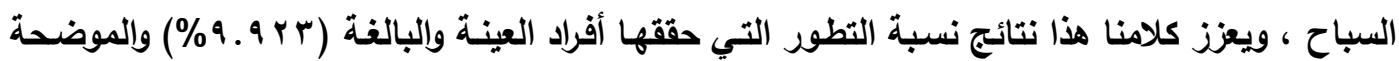

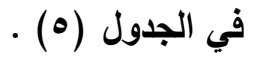

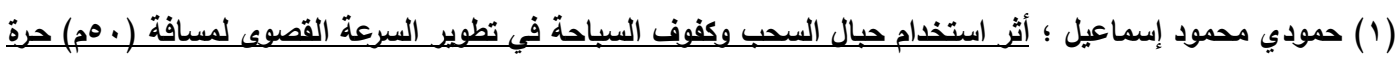

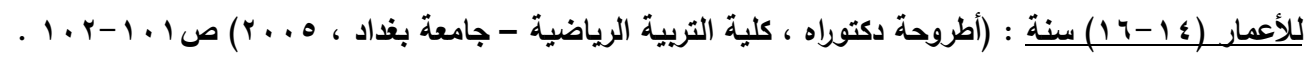


هبلة كلية التربية الرياضية .... جاهعة بغداد ..... المبلد r....... العدد ا

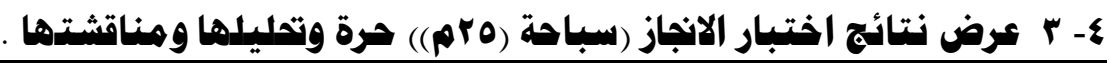
ع- r- 1 عرض نتائج الوسط المسابي والانــراف المعيساري في الاختبـارين القبلـي والبعـدي في

اختبار الانجاز (سباحة (مro) حرة) وتمليلها.

(7) الجدول

يبين الوسط الحسابي والانحراف المعياري في الاختبارين القبلي والبعدي لاختبار الانجاز

(سباحة (0 بم) حرة)

\begin{tabular}{|c|c|c|c|c|c|}
\hline \multicolumn{2}{|c|}{ الاختبار البعدي } & \multicolumn{2}{|c|}{ الاختبار القبلي } & \multirow{2}{*}{ وحدة } & \multirow{2}{*}{ المتغير / الاختبار } \\
\hline$\varepsilon$ & سَ & $\varepsilon$ & سَ & & \\
\hline $1.99 \leq$ & $\varepsilon 1.1 \wedge \wedge$ & $\cdot . \leqslant 0 r$ & $\varepsilon \Lambda . \cdot T \leqslant$ & ثا & الانجاز (سباحة (0 (م) حرة) \\
\hline
\end{tabular}

الجدول († ) يبين الوسط الحسـابي والانحراف المعياري في الاختبارين القبلي والبعدي لاختبار

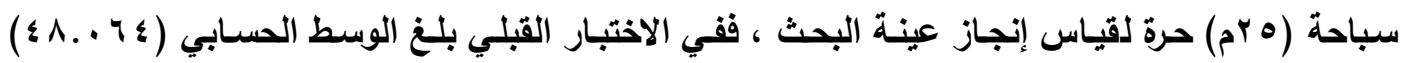

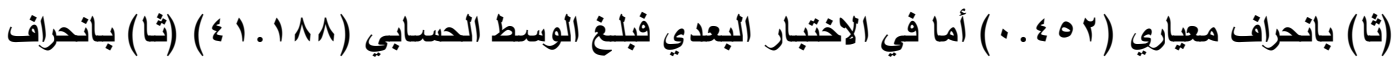

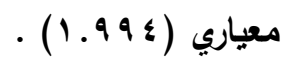

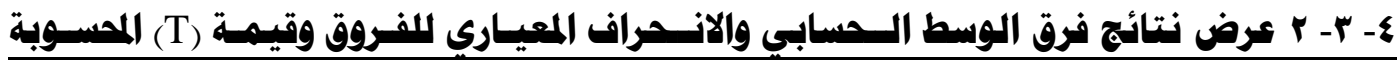
ودلالة الفرق والنسبة المئوية للتطور في الاختبارين القبلي والبعدي في اختبـار الانجـاز (سبساحة

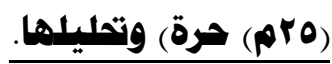

\section{(v) الجدول}

يبين فرق الوسط الحسابي والانحراف المعياري للفروق وقيمة (T) المحسوية ودلالة الفرق والنسبة المئوية للتطور في الاختبارين القبلي والبعدي لاختبار الانجاز (سباحة (ه بم) حرة)

\begin{tabular}{|c|c|c|c|c|c|c|}
\hline التطور \%بة & الفرق & مستوى الخطأ & 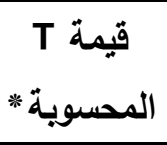 & ع ف & فَت & القدرة / الاختبار \\
\hline $1 \leq .4 .7$ & معنوي & $\cdots \cdot 1$ & $\Lambda . r \leq \varepsilon$ & $1 . \wedge \leqslant \mu$ & $7 . \wedge \vee 7$ & الانجاز (سباحة (هץم) حرة) \\
\hline
\end{tabular}

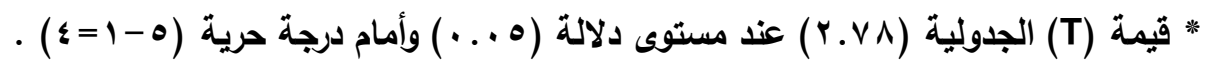
* معنوي عند مستوى الخطأ (ه . . ) إذا كان مستوى الخطأ أصغر من (ه . . . .) . 


\section{هبلة كلية التربية الرياضية .... جاهعة بغداد ..... المبلد rr..... العدد I}

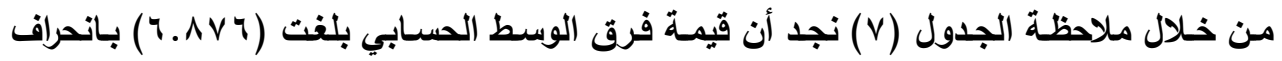

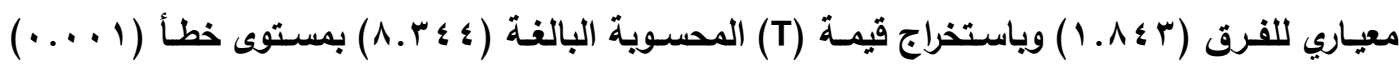

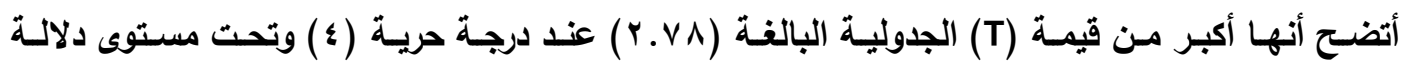

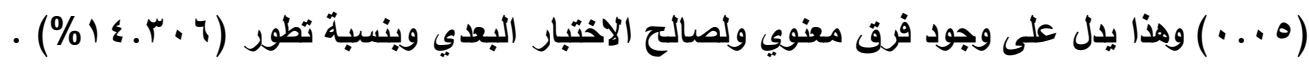

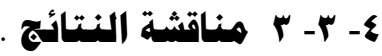

من خلال ملاحظة الجدول (V) يتضـح بأن هنـاك فرقاً ذا دلالـة معنويـة لصـالح الاختبار البعدي وتعزو الباحثة هذا التطور الى فاعلية التمرينـات المتنوعة داخل حوض السباحة وعلى اليابسـة والتي تم لمان

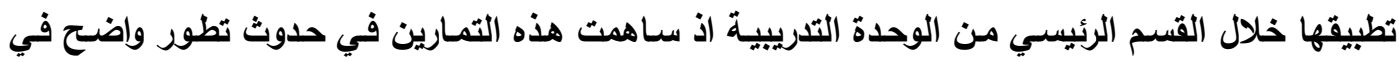

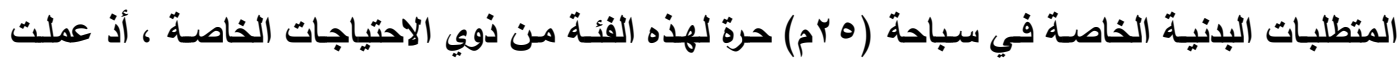
هذه التمـارين على تحسين كل من (القوة المميزة بالسرعة والسرعة القصوى وتحمل السرعة ) لعضـلات

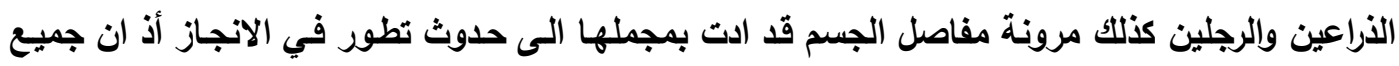
هذه القدرات كانت مكمله الواحدة للأخرى . بمعنى أن هذه التمارين المتنوعة كان هدفها يصب في تحسين وزيادة سرعة السباح لتحقيق أفضل انجاز ، وتم الوصول إلى ذلك عن طريق تطور القوة العضلية للعضلات العاملة في سباحة هذه

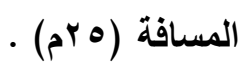

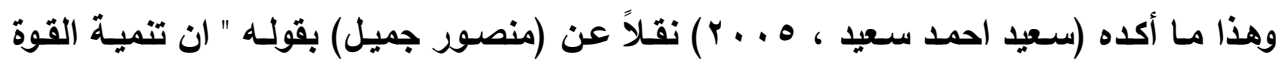

العضلية ستعمل على تطوير عنصر السرعة " (1) .

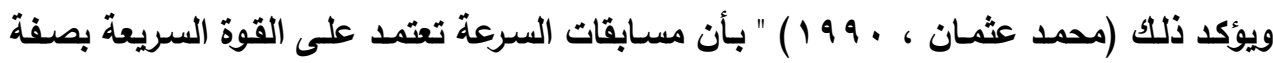

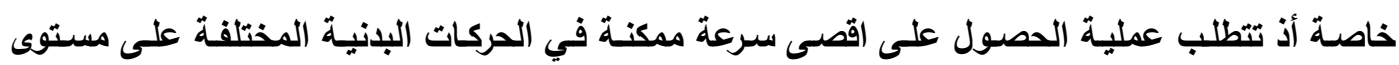

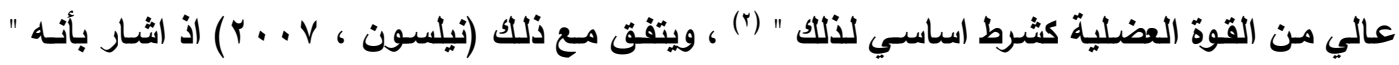

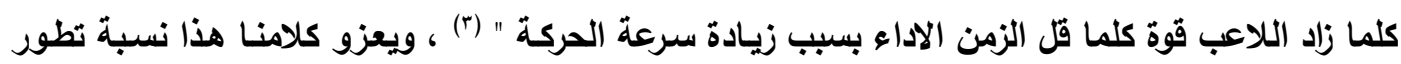

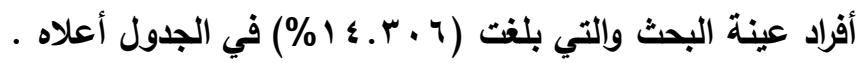

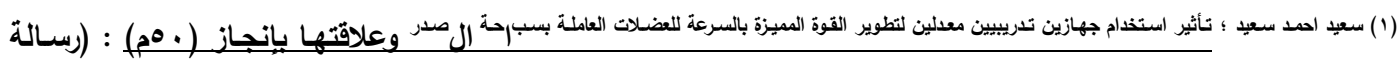

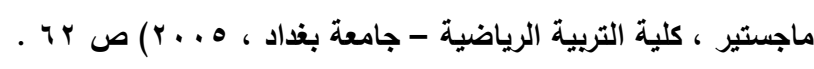

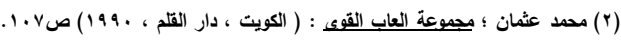

(3) Nelson K. R. ; opcit, 2007, P 99-100 . 


\section{هجلة كلية التربية الرياضية .... جاهعة بغداد ..... المبلد r ..... العدد I}

\section{البـاب الخاهـسـ}

0 - - الاستنتاجــات والتوصيــات

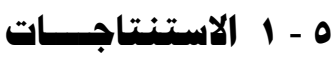

من خلال عرض النتائج وتحليلها ومناقشتها توصلت الباحثة إلى الاستتتاجات الآتية : 1. إن التمـارين المتنوعة في المـاء واليابسـة أدت إلى تطوير القدرات البدنيـة وانجـاز (ه مج) لأفراد عينة البحث .

r. حدوث تطور واضـح فـي السـرعة القصـوى للـرجلين والـذراعين وإلقـوة المميزة بالسـرعة نتيجـة استخدام بعض الوسائل المساعدة . r. إن استخدام مبدأ التدرج في الحمل التدريبي بالطريقة المتموجة في شدة التدريب كان لـه الأثر

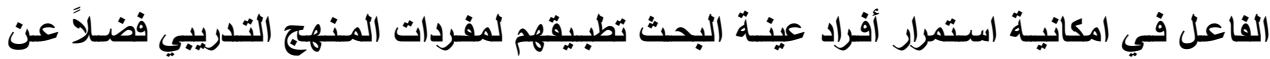
استخدام بعض الحوافز من الجوائز والهـايا .

\section{r - \\ من خلال ما تقدم من استنتاجات توصي الباحثة ما يلي :}

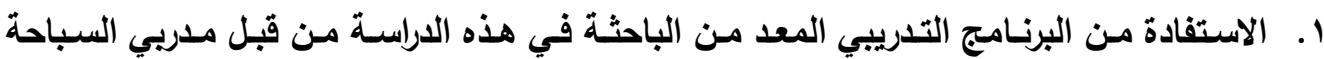

$$
\text { •لخواص }
$$

r . تطبيق تمـارين على اليابسـة خـلال الوحدات التدريبية كونها تسـاهم في تطوير القدرات البذنيـة المختلفة للسباح وحسب اختصاصـه في مسـافة السباحة دون التركيز فقط على تمـارين داخل

$$
\text { حوض السباحة لأنها ستعمل ايضاً على إبعاد الملل للرياضي . }
$$

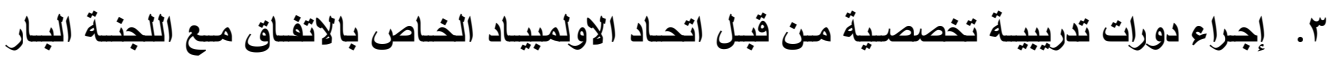
أولمبية لغرض زيادة الخبرات التدريبية العاملين مع هذه الفئات .

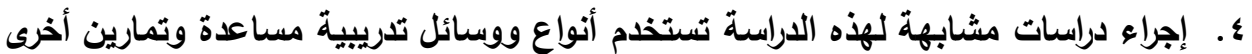

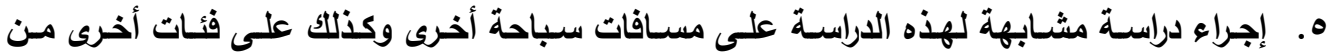




\section{المسادر العربيسة والأجنبيسية}

ابتهاج ناجي كريم ؛ تأثير منهج تعليمي تدريبي مقترح في بعض المهارات الأساسية والقدرات

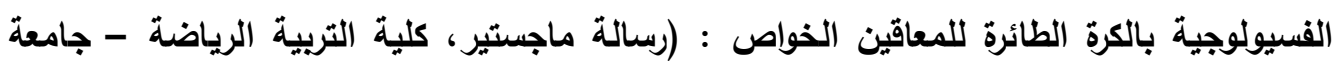

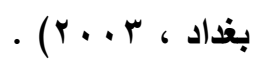

\& أبو العلا احمد عبد الفتاح ؛ سلسلة المراجع في التربية البانية والرياضية (فسيولوجيا التدريب

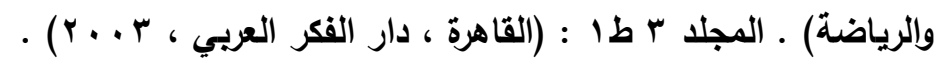

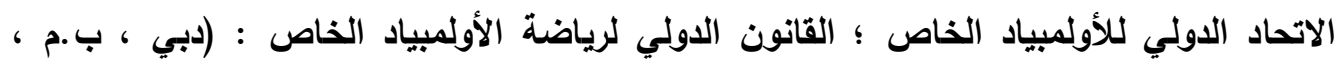
. ( $) .9$

أمل معوض الهجرسي ؛ تربية الأطفال المعاقين عقلياً ـ طا : (الرياض ، دار الزهراء للنشر والتوزيع . ( r... ^ ،

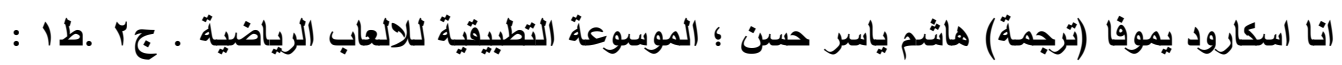

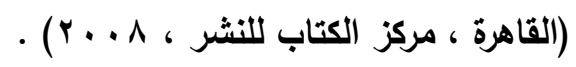

بسطويسي احمد ؛ أسس ونظريات التدريب الرياضي : (القاهرة ، دار الفكر العربي ، 999 ، 99 ) ) .

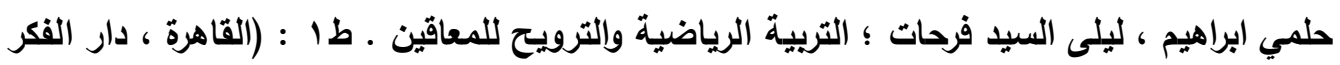

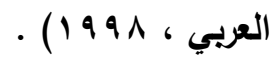

حمودي محمود إسماعيل ؛ أثر استخدام حبال السحب وكفوف السباحة في تظوير السرعة القصوى

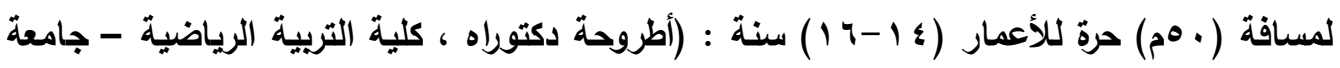

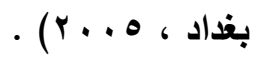
خولة ابراهيم محيل ؛ بناء وتقتين بطارية اختبار بانية ووظيفية بألعاب القوى لذوي التخلف العقلي

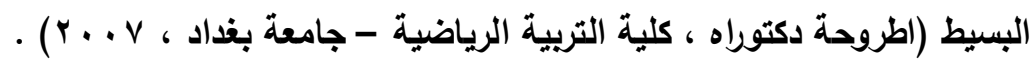

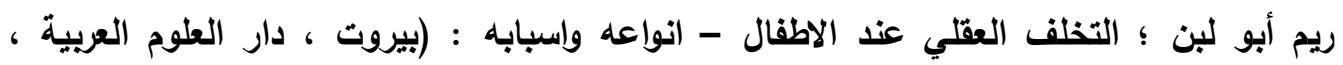
• ( $r . v$

سعيد احمد سعيد ؛ تأثير استخدام جهازين تدريبيين معدلين لتطوير القوة المميزة بالسرعة للعضلات

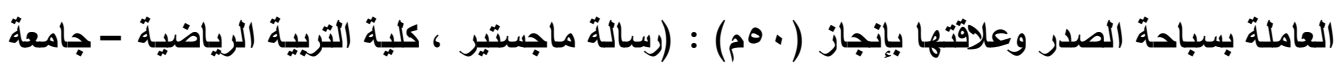

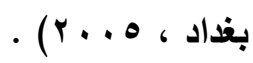
فوقية حسن رضوان ؛ التشخيص التكاملي والفارقي للإعاقة العقلية : (القاهرة ، دار الكتاب الحديث ، . ( r... $\Lambda$ 


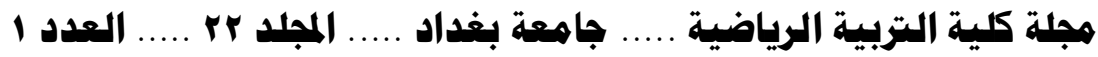

قاسم حسن حسين ؛ علم التدريب الرياضي في الأعمار المختلفة ـ طا : (القاهرة ، دار الفكر العربي . (1991،

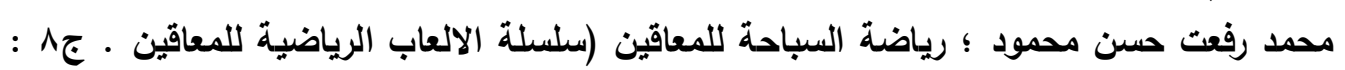

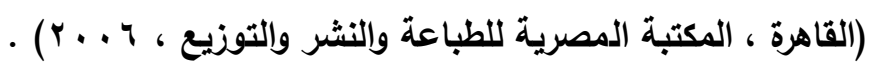

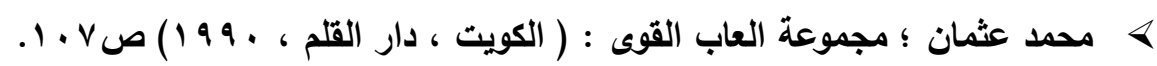

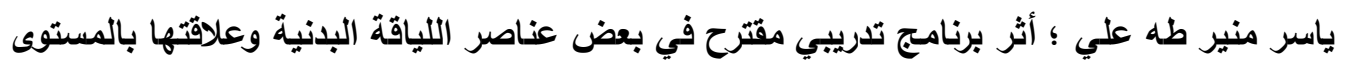

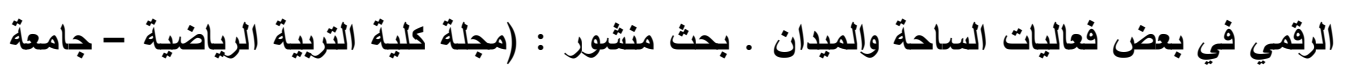

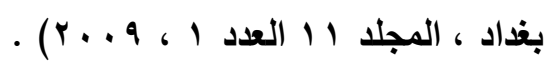

$>$ Gannet H. ; Classification and etiological factors in mental retardation : (Journal of the American Collage of mental retardation, vol. 124,2009$)$.

$>$ http//www.somena.org/2009.

$>$ Nelson K. R. ; Training in track \& Field : (New York, Copal point publishers, 2007).

$>$ Scott K. Powers, Edward T. Howley ; Exercise physiology Theory and application to Fitness and performance . 10th Ed : (New York, McGraw - Hill companiespub, Inc . 2008) .

$>$ Whelley K. \& others ; Families of young adults with mental retardation transitioning into adult services . 2nd Ed : (USA, library of congress cataloging, 2008) .
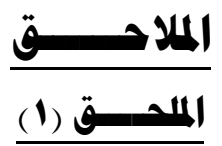

يبين أسسماء فريق العمل المساعد

\begin{tabular}{|c|c|c|c|}
\hline مكان العمل & الصفة & الاسم & $ت$ \\
\hline كلية التربية الرياضية - جامعة بغداد & مدرس & د. زيدون جواد محمد & .1 \\
\hline كلية التربية الرياضية - جامعة بغداد & مدرس & د. أحلام شغاتي &.$r$ \\
\hline كلية التزبية ابن الهيثم - جامعة بغداد & لاعب سباحة & انمار سامي بشار & r \\
\hline
\end{tabular}


هجلة كلية التربية الرياضية .... جاهعة بغداد ..... المبلد r...... العدد ا...

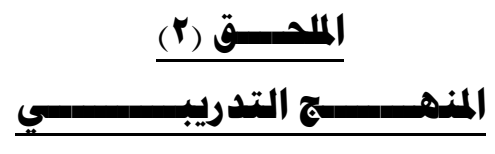

القــوة الميميــزة بالسرعهـــة

I. تمارين القوة المميرة بالسرعة لعضلات الرجلين

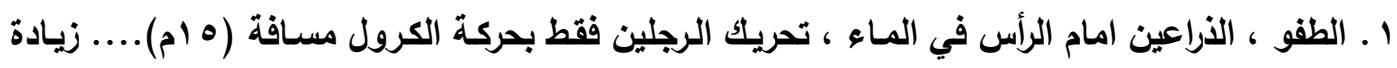

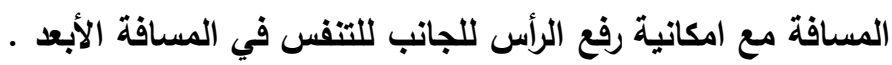

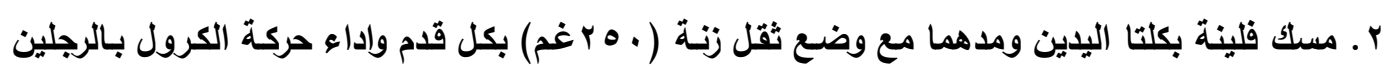

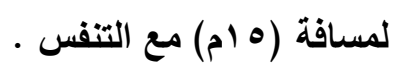

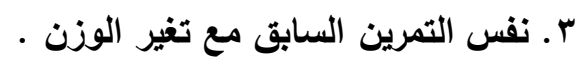
ـ ـ مسك حافة المسبح بكلتا اليدين ومد الجسم اماماً واداء حركة الكرول بالقدمين لمدة (ه الثا) .

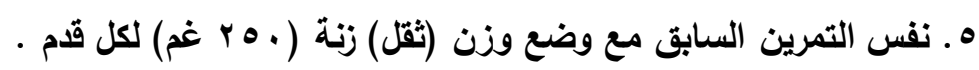
7. الحجل على رجل واحدة لمسافة (هم) ثم التبديل على الرجل الاخرى لمسافة (نم) أيضاً.

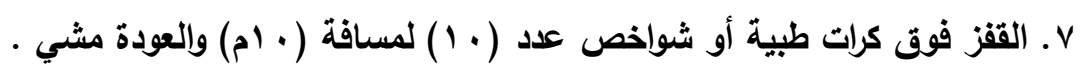

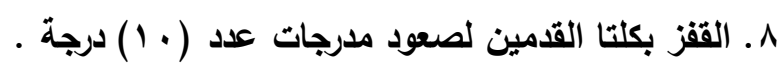

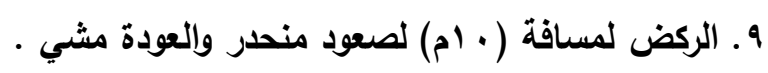

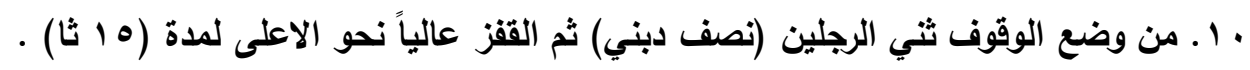

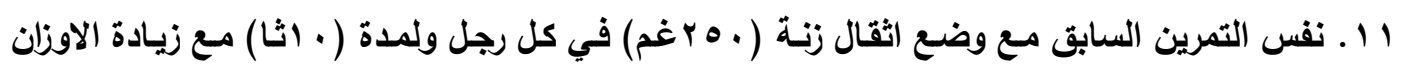
بتقدم الوحدات التدريبية .

r r. تمارين القوة المميزة بالسرعة لعضلات الذراعين 1 الطقو ، حركة الرجلين بصورة مستمرة مع استناد احدى الذراعين على فلينة ، تحريك ذراع واحدة ثم الثم

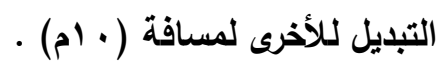
r . محاولة تثبيت القدمين بوضع الطفو الافقي بدون استخدام أداة تحريك الذراعين بحركة الكرول لمسافة 


\section{هجلة كلية التربية الرياضية .... جاهعة بغداد ..... المبلد r ..... العدد I. I}

r. تثبيت القدمين بحافة الحوض مع مد الجسم للأمام بصورة مستقيمة وأداء حركة السباحة بالذراعين

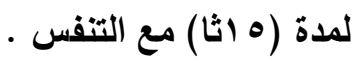

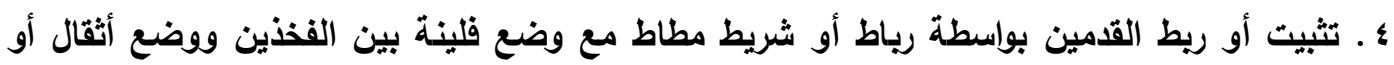

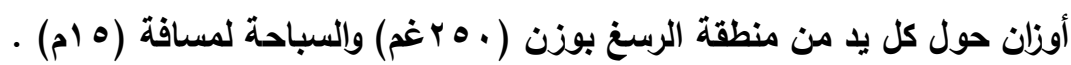

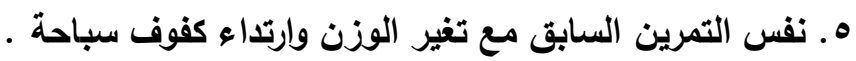

7 ـ الاستلقاء على مسطبة على جهة البطن ووضع أوزان على اليا وتأدية حركة السباحة لمدة (ه 1 أثان

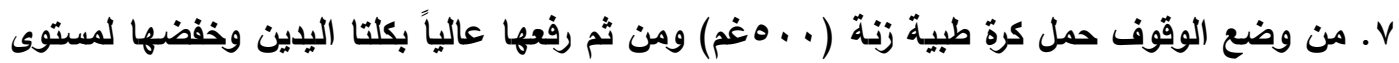
الصدر ولمدة (ه انثا). ^. حمل كرة طبية زنة ( . . هغم) بكلتا اليدين أمام الصدر ومد اليدين للأمام ثم إرجاع اليدين إلى خلف

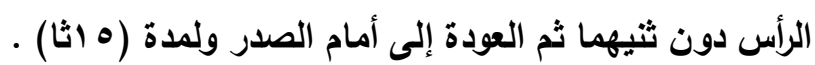

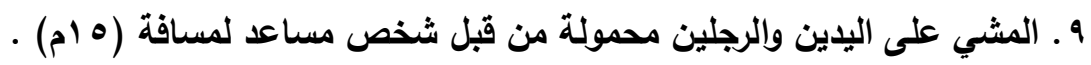
• 1 ـ من وضع الاستتاد الأمامي حمل الرجلين بواسطة زميل ومن ثم السير على اليدين بسرعة لمسافة $\cdot(p \cdot)$

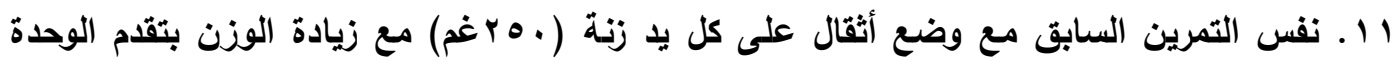
التدريبية. r ا ـ نفس التمرين رقم (9) ولكن على منحدر (صعود) .

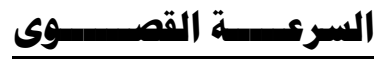

\section{ا . تمارين السرعة القصوى لعضلات الرجلين}

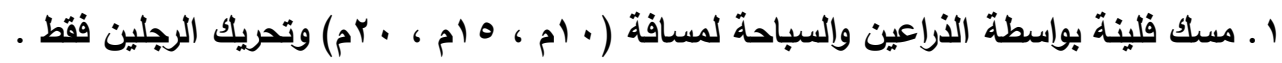

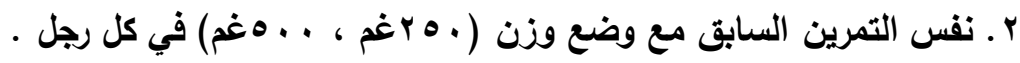

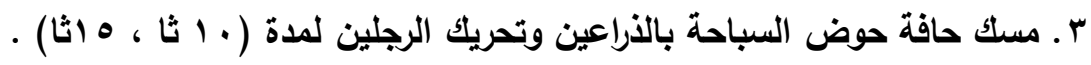

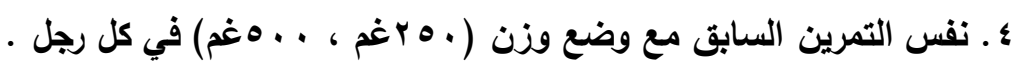

\section{r. تمارين السرعة القصوى لعضلات الذراعين}

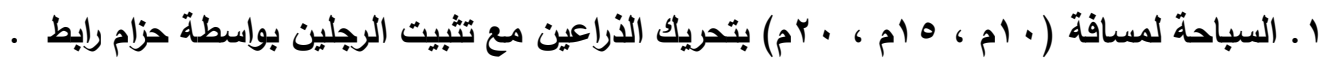




\section{هجلة كلية التربية الرياضية .... جاهعة بغداد ..... المبلد r...... العدد I}

r ـ تثبيت القدمين على حافة حوض السباحة وتحريك الذراعين بسرعة قصوى (السباحة الحرة) لمدة ( المبل

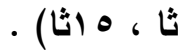

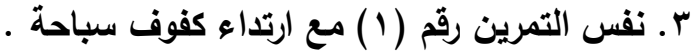

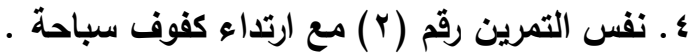

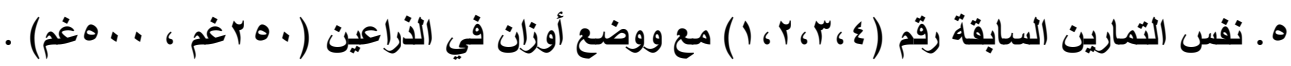

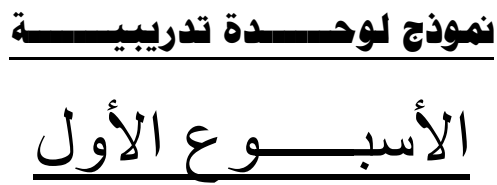

الهُف من الوحدة : تطوير القوة المميزة بالسرعة للرجلين والذراعين

الثدة : • ا

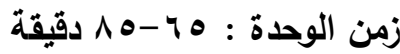

\begin{tabular}{|c|c|c|c|c|c|c|c|}
\hline الملاحظات & المجاميع بين & المجاميع & التكرارة بين & التكرار & \multicolumn{2}{|c|}{ التمرين } & تطوير \\
\hline & Tr-r & - & I I, r. & 0 & تمرين رقم (؛) & للرجلين & \multirow{4}{*}{ بالسريزة } \\
\hline & T & - & מ & 0 & تمرين رقم (r) & للأراعين & \\
\hline & Tr & - & د., & 0 & تمرين رقم (9) & للرجلين & \\
\hline & r r r & - & . & 0 & تمرين رقم (9) & للأراعين & \\
\hline
\end{tabular}

الهُف من الوحدة : تطوير السرعة القصوى للرجلين والذراعين الثدة : . 9 \%

زمن الوحدة : هوهـه دقيقة

\begin{tabular}{|c|c|c|c|c|c|c|c|}
\hline الملاحظات & الرجاميع بين & المجاميع & التكراحة بين & التكرار & \multicolumn{2}{|c|}{ التمرين } & القدوير \\
\hline & دo_ ₹ & - & دr, r. & $\theta$ & تمرين رقم (1) & للرجلين & \multirow{4}{*}{ القصوى } \\
\hline & $10_{-} \xi$ & - & دr, r. & 0 & تمرين رقم (1) & للازراعين & \\
\hline & 20 - & - & $\Delta r, r$. & 0 & تمرين رقم (r) & للرجلين & \\
\hline & ـ צ & - & دr, r. & 0 & تمرين رقم (Y) & للاذر اعين & \\
\hline
\end{tabular}

